\title{
Vaccaria segetalis: A Review of Ethnomedicinal, Phytochemical, Pharmacological, and Toxicological Findings
}

Meng Tian, Yuwen Huang, Xin Wang, Maosheng Cao, Zijiao Zhao, Tong Chen,
Chenfeng Yuan, Nan Wang, Boqi Zhang, Chunjin Li* and Xu Zhou*

College of Animal Sciences, Jilin University, Changchun, China

Vaccaria segetalis is a dry mature seed of Vaccaria hispanica (Mill.) Rauschert, which belongs to the genus $V$. segetalis (Neck.) Garcke. There are multiple medicinal parts of $V$. segetalis, according to the records, including roots, stems, leaves, flowers, and seeds, which should be used together. Currently, $V$. segetalis is most frequently used in the treatment of menstruation, dysmenorrhea, breast milk stoppages, and chylorrhea. Numerous studies present historical evidence of the use of $V$. segetalis to treat several diseases and describe its beneficial effects including prolactin- (PRL-) like, estrogen-like, antitumor, antiangiogenesis, and antioxidant activity. We summarized the period from January 1980 to December 2019 regarding V. segetalis. This review paper indicates that $V$. segetalis has promising clinical applications. The main active ingredients of the plant have been elucidated in recent years. We summarized the previously and newly discovered pharmacological effects of $V$. segetalis in addition to its active ingredients, ethnopharmacological uses, and toxicological properties, and provided a focus for future research.

Keywords: Vaccaria segetalis, prolactin activity, estrogen-like activity, anti-tumor activity, anti-oxidant activation

\section{INTRODUCTION}

Vaccaria segetalis (Neck.) Garcke is an annual herb and is widely distributed worldwide throughout the cold temperature zone. The seeds of $V$. segetalis, which are known as Wang Bu Liu Xing, have been used in traditional Chinese medicine (TCM) to treat amenorrhea, dysmenorrhea, lactation failures, and carbuncles (Sang et al., 2003). V. segetalis has been used in China for 2000 years as documented in the oldest materia medica Shen Nong Ben Cao Jing. In recent years, being its clinical application more extensive, and many new clinical applications, such as the treatment of shingles (Min-ying, 2005), gallstones (Zhi-hong and Cai-ying, 1989), hypertension (Liu, 2018), and rhinitis (Liang and Xiu-jun, 2013), have been identified. V. segetalis is composed of several chemical components. Saponins (Ma et al., 2008), flavonoids (Wang et al., 2011), polysaccharides (Qing et al., 2014), and cyclic peptides (Sang et al., 2002) are believed to be the principal active constituents of $V$. segetalis. The seeds also contain components such as coumarins, lipids, fatty acids, and metallic elements (Jin-Ling et al., 2014). Recently, an increasing number of studies have suggested that $V$. segetalis extract has various bioactivities, such as prolactin- (PRL-) like, estrogen-like, antitumor, antiangiogenesis, and antioxidant activity, and it is also shown to dilate blood vessels and relieve osteoporosis (Li-Fan and Liang, 2007). This article also summarizes toxicological research regarding $V$. segetalis. 
Complementary/alternative medicine has developed rapidly in recent years, and its use has gradually expanded globally. The use of Chinese herbal medicine as a part of complementary/alternative medicine has been the focus of many scholars. Although a few literature studies have described $V$. segetalis to date, no article has systematically summarized and evaluated the research results. We conducted this review to summarize the existing literature studies and to focus on analyses of the chemical constituents and pharmacological activities of $V$. segetalis. Our goal is to permit other researchers to more easily review existing research and provide new directions for future research.

\section{ETHNOPHARMACOLOGICAL USES}

\section{Preparation of $\boldsymbol{V}$. segetalis}

Dry mature seeds from $V$. segetalis were prepared by using a multistep process. $V$. segetalis has different traits in different preparation stages (Tian-Yi, 2011). A specific preparation method is described below. In the first stage, after the fruits mature in summer, the plants are cut and dried. Then, the seeds are beat and dried. During this time, the seed is a black sphere with a diameter of approximately $2 \mathrm{~mm}$. In the second stage, the seeds are fried until most seeds burst into white flowers. In the final stage, the seeds that burst into white flowers are ground into powder.

\section{Methods of Administration}

There are three administration methods for different preparation stages of $V$. segetalis because of its different traits. In the first type, seeds can be applied directly by pressing acupoints. In the second type, the seeds are fried until the white flowers burst, and the seeds are decocted in water. In the third type, the ground powder is applied directly to the affected area.

\section{Indication}

The seeds of $V$. segetalis are often used as black spheres in acupressure methods. Based on the TCM theory, acupoints are the specifically chosen sites for physical stimulation (Rong et al., 2011). A few studies have revealed that stimulating different acupoints on the body surface could provide various therapeutic benefits (Li et al., 2015). Previous research illustrated that pressing acupoints with seeds can improve hypertension. In one study, Liu (2018) selected the auricular points that were related to blood pressure, pressed one seed at each acupoint, and kneaded each acupoint for 3-5 min. This treatment was

\footnotetext{
Abbreviations: PRL, Prolactin; LPS, Lipopolysaccharide; ERK, Extracellular signal-regulated kinases; JNK, C-Jun N-terminal kinase; CPID, Chronic pelvic inflammatory disease; MPF, Man-Pen-Fang; IL-6, Interleukin-6; TNF$\alpha$, Tumor necrosis factor- $\alpha$; TGF- $\beta$, Transforming growth factor- $\beta$; COX-2; VNE, Cyclooxygenase-2; Vaccaria n-butanol extract; PECAM-1, Platelet-endothelial cell adhesion molecule-1; A549, Human; lung carcinoma; Panc-1, Human pancreatic carcinoma; MCF-7, Human breast adenocarcinoma; PC-3, Human prostate adenocarcinoma; LNCaP, Human prostate carcinoma; HMECs, Human mammary epithelial cells; CAM, The chick chorioallantoic membrane; bFGF, basic fibroblast growth factor; VEGF, Vascular endothelial growth factor; HepG2, Human hepatoma cells; ROS, Reactive oxygen species; DBP, Dibutyl phthalate; $\mathrm{GH}$, Growth hormone; IGF, Insulin-like growth factor.
}

performed thrice a day, and the contralateral acupoints were alternatively pressed every 3 days. After 2 weeks of treatment, the hypertension symptoms of a patient had resolved (Liu, 2018). Gallstones can also be treated in this manner. In another study, the researchers used the seeds of $V$. segetalis to press the gallbladder, liver, duodenum, and sympathetic points on both sides of the ears of patients dozens of times and found that the gallbladder contracted significantly. Consequently, small stones and silt-like stones in the gallbladder were discharged into the intestinal lumen with bile, and then excreted from the body (Zhihong and Cai-ying, 1989). In addition, this method was used to treat rhinitis. A research team also used the seeds to press the ear points that were related to the nose 3-5 times a day, for 13 min each time. Ear points were changed every 3 days, switching between the two ears, and the course of treatment was 10 days (Liang and Xiu-jun, 2013). V. segetalis as a white flower after frying is often used in water decoctions. V. segetalis has also been used in combination with other Chinese herbal medicine to treat gonorrhea and promote the milk production. According to The Precious Mirror of Hygiene (AD 1343), ancient Chinese herbalists used $V$. segetalis to boost the milk production and milk lactation. The traditional Chinese herbal medicine prescription consists of equal amount of the spike of Dianthus superbus L., Ophiopogon japonicas (L.f.) Ker-Gawl (inner column removal), $V$. segetalis, fossil fragments (ancient mammals such as elephants, rhinos, three-toed horses, cattle, and deer), and the scale of Manis pentadactyla Linnaeus to the total of $50 \mathrm{~g}$. The components are mixed and ground into a powder. In total, $5 \mathrm{~g}$ of the mixture are consumed with hot wine thrice a day. Then, $5 \mathrm{~g}$ of the mixture are added to a soup consisting of pork knuckle and Akebia quinata (Houtt.) Decne. and consumed thrice a day. Finally, the remaining mixture is rubbed on the left and right breasts 30 times with a wooden comb after consuming the aforementioned soup thrice a day (Tian-Yi, 2011). In recent years, a new application method has been to grind the white flower into a powder for an external application on the affected area. This was proven to be effective for treating shingles (Min-ying, 2005).

In summary, the applications of $V$. segetalis have been gradually expanded and improved with the accumulated research data. V. segetalis can be used externally or internally. It has been used for a long time based on the physical properties of the seeds to stimulate acupuncture points to treat diseases and their mixing in water decoctions with the other Chinese herbs. The newest application method is a direct application of the powder to the wound surface to treat shingles. We speculate that these activities are related to the active ingredients in seeds. We believe that the in-depth studies of $V$. segetalis will increase its clinical applications.

\section{PRIMARY ACTIVE INGREDIENTS IN $\boldsymbol{V}$. SEGETALIS}

Vaccaria segetalis is mainly composed of saponins, cyclic peptides, flavonoids, and polysaccharides, and the other components include volatile oils, coumarins, lipids, and 
fatty acids. Several studies have investigated these active substance constituents.

\section{Saponins}

Several types of saponins are present in the seeds of $V$. segetalis. These saponins primarily include quillaic acid compounds, which account for $\sim 65 \%$ of the total (Table 1). The other saponins include gypsogenin bisdesmosides $(\sim 15 \%)$, gypsogenic acid monodesmosides $(\sim 10 \%)$, and vaccaric acid bisdesmosides $(\sim 10 \%)$. The structures of the known saponins are summarized in Table 1. Triterpenoid saponins are the main components of $V$. segetalis. They are oleanol-type pentacyclic triterpenoids, which are also known as $\beta$-aromatic alkanes. These compounds are widely distributed in the plant kingdom. Triterpenoid saponins mostly have antioxidant (Guan et al., 2013), antitumor (Bozak et al., 1990; Haralampidis et al., 2002; Choi et al., 2005), and anti-inflammatory effects (Bernard et al., 2001; Banno et al., 2005; Guan et al., 2013). They also protect the cardiovascular system through their antihypertensive, antiatherosclerotic, and vasodilatory effects (Rosalía et al., 2004). The main pharmacological activities of Panax ginseng C. A. Meyer, Glycyrrhiza uralensis Fisch., and Bupleurum L, which are widely used in daily life, are derived from their saponin components.

\section{Cyclic Peptides}

Cyclic peptides have been found in several medicinal species such as Pseudostellaria heterophylla Miq., Lycium chinense Mill., and Psammosilene tunicoides, and exhibit a wide range of structuredependent bioactivities (Tan and Zhou, 2006). Cyclic peptides are important components of $V$. segetalis (Dahiya and Dahiya, 2021). With the development and integration of modern medicine and traditional complementary medicine, the roles of cyclic peptides have been further confirmed. To date, eight cyclic peptides have been isolated from the seeds of $V$. segetalis (Table 2). Cyclic peptide molecules have antitumor activity (Feng et al., 2012), and they regulate uterine contraction, which implies estrogenlike activity for segetalins A, B, G, and H (Itokawa et al., 1995; Yun et al., 1997). In addition, a few studies illustrated that segetalins $\mathrm{A}, \mathrm{D}, \mathrm{F}$, and $\mathrm{G}$ have vasodilatory activity against norepinephrineinduced aortic contraction in rats (Morita et al., 1997a). The pharmacological effects of cyclic peptides provide new options for the treatment of diseases.

\section{Flavonoids}

Flavonoids comprise a broad class of ketone containing compounds that exist widely in nature. Flavonoids are widely distributed in plants in the form of glycosides, which are called flavonoid glycosides. In particular, Sophora japonica, Scutellaria baicalensis, Pueraria lobata, and Ginkgo biloba are rich in flavonoids. The structure of vaccarin, a flavone isolated from the seeds of $V$. segetalis, is presented in Figure 1 (Sang et al., 2000c). Flavonoids have many effects, such as protective effects on endothelial cells (Kozlowska and Szostak-Wegierek, 2014), hypoglycemic effects (Chen et al., 2017), antiviral effects (Zakaryan et al., 2017), and the ability to enhance lactation capacity (Tong et al., 2013).

\section{Polysaccharides}

Polysaccharides are formed by the polymerization of more than 10 monosaccharide molecules via glycosidic bonds. They have high molecular weights, and they usually consist of several hundreds to thousands of monosaccharide molecules. Polysaccharides and their derivatives, such as lentinan, Astragalus polysaccharide, Polyporus polysaccharide, Lycium barbarum polysaccharide, and Ganoderma lucidum polysaccharide, are bioactive substances in TCM. They have antitumor (Mao et al., 2016; Tang et al., 2016), antioxidant (Hui et al., 2019), and anti-inflammatory effects (Wang et al., 2019), and promote cell proliferation (Zheng et al., 2014). Polysaccharides have been isolated from the seeds of $V$. segetalis in recent years (Zhou et al., 2015).Various active ingredients in $V$. segetalis provide a theoretical and realistic basis for the study of its pharmacological effects.

\section{Other Components of $\boldsymbol{V}$. segetalis}

$V$. segetalis also contains coumarins, lipids, fatty acids, and other ingredients, along with adenosine and adenine. The main components of $V$. segetalis volatile oils are oleic acid amide, n-octadecane, myristylamide, and n-pentadecane (Yun et al., 1998). In addition to the currently known major active ingredients, several unknown ingredients of the plant require further investigation to be identified.

\section{PHARMACOLOGICAL ACTIVITY OF $\boldsymbol{V}$. SEGETALIS}

Recently, $V$. segetalis has mainly been used in folk medicine based on its anti-inflammatory, antioxidant, anti-angiogenic, and antitumor effects, in addition to its ability to promote vasodilation, muscle contraction, and lactation. The active ingredients responsible for these effects are polysaccharides, saponins, flavonoids, and cyclic peptides (Peng et al., 2014). We will now specifically introduce its pharmacological activities.

\section{Anti-inflammatory Activity}

According to Shen Nong Ben Cao Jing, V. segetalis has been used to treat urinary symptoms such as blood strangury for 2000 years. Gonorrhea in Chinese medicine refers to diseases such as urinary tract infection, prostatitis, and seminal vesicle inflammation. The traditional Chinese herbal medicine prescription is as follows: $30 \mathrm{~g}$ of the seeds of $V$. segetalis and $6 \mathrm{~g}$ each of the roots of Angelica sinensis Diels, Chinese teasel, Paeonia lactiflora Pall., and Salvia miltiorrhiza are orally administered as two doses via decoction (Zhu-mo, 2005). Based on an extensive application of $V$. segetalis in the treatment of inflammatory diseases, we searched and collated the articles published in the past 30 years to explore the intrinsic mechanism of $V$. segetalis in the treatment of inflammatory diseases.

Hypaphorine from the different sources exhibits antiinflammatory properties (Silva et al., 2012). V. segetalis extract, along with its hypaphorine, displayed anti-inflammatory activity both in vitro and in vivo (Aswad et al., 2018). In this study, mice were intraperitoneally injected with $200 \mathrm{mg} / \mathrm{kg}$ of the $6.019 \%$ of Vaccaria hydroalcoholic extract, and the results suggested that it 
TABLE 1 | Saponins present in the seeds of Vaccaria segetalis.

\section{Saponins}

Formulae

$\mathrm{C}_{69} \mathrm{H}_{106} \mathrm{O}_{33}$

\section{Segetosides}

Segetoside B

\section{Structure}

Pharmacological

activities

Inhibition of luteal

cell
References

Sang et al., 2002

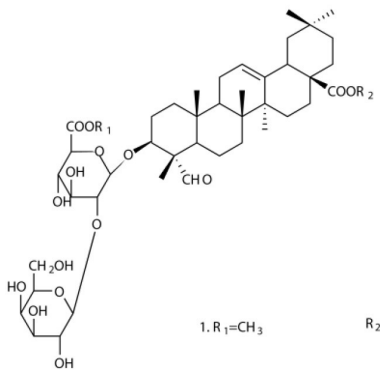

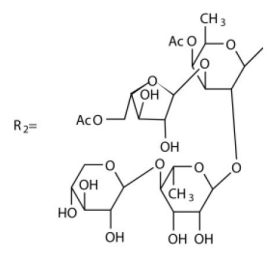

Segetoside $\mathrm{C} \quad \mathrm{C}_{56} \mathrm{H}_{88} \mathrm{O}_{32}$

$R=\overbrace{O A C}^{\mathrm{OO}}$

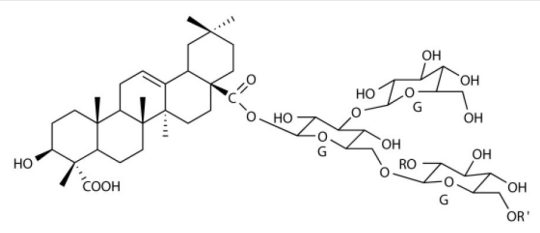

Unknown

Sang et al., 1999

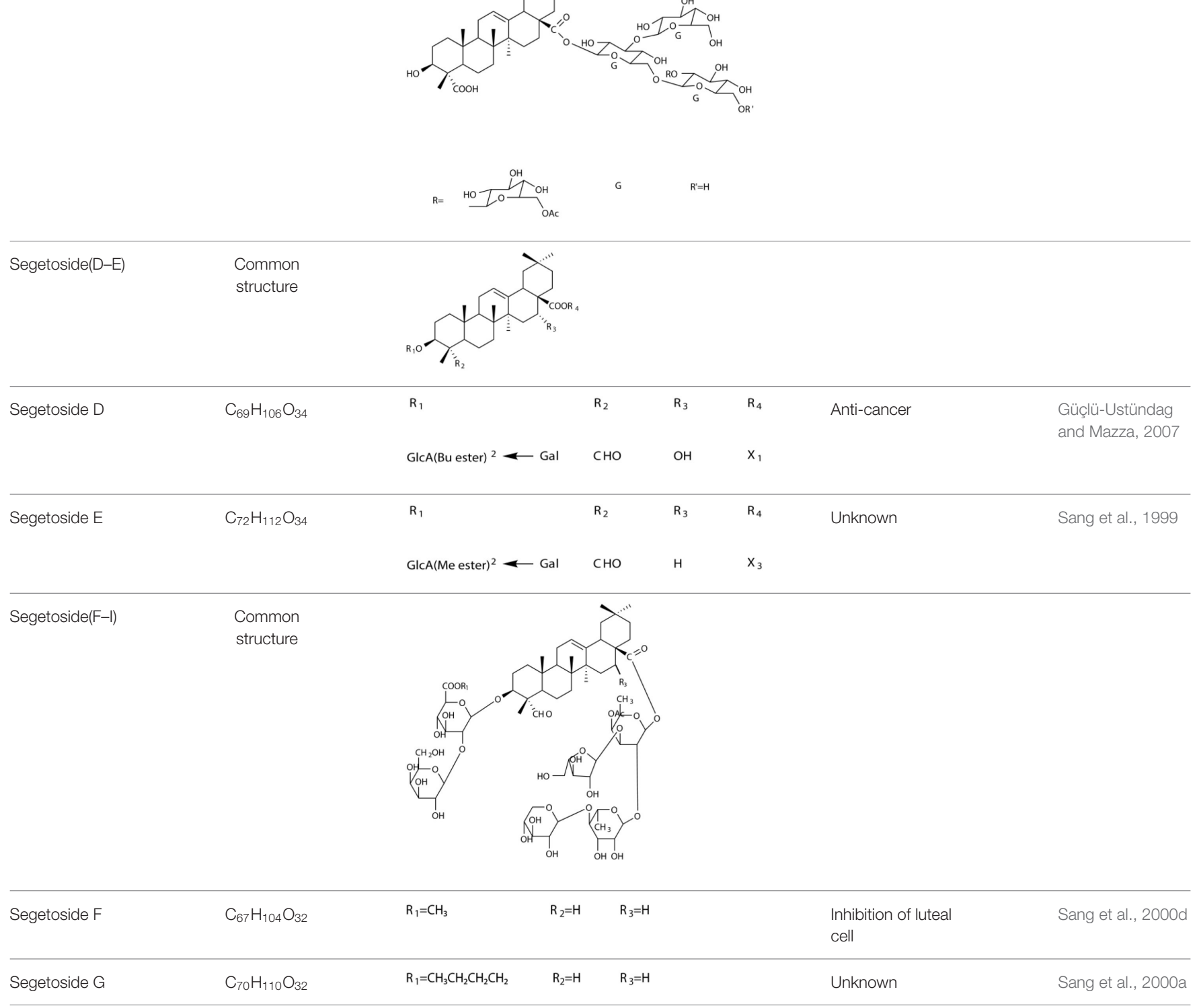

(Continued) 
TABLE 1 | Continued

\begin{tabular}{|c|c|c|c|c|}
\hline Saponins & Formulae & Structure & $\begin{array}{l}\text { Pharmacological } \\
\text { activities }\end{array}$ & References \\
\hline Segetoside H & $\mathrm{C}_{68} \mathrm{H}_{104} \mathrm{O}_{33}$ & $\mathrm{R}_{1}=\mathrm{H} \quad \mathrm{R}_{2}=\mathrm{Ac} \quad \mathrm{R}_{3}=\mathrm{H}$ & Unknown & Sang et al., 2000a \\
\hline Segetoside I & $\mathrm{C}_{68} \mathrm{H}_{104} \mathrm{O}_{34}$ & $\mathrm{R}_{1}=\mathrm{H} \quad \mathrm{R}_{2}=\mathrm{Ac} \quad \mathrm{R}_{3}=\mathrm{OH}$ & $\begin{array}{l}\text { Anti-tumor activity; } \\
\text { Activation of } \\
\text { apoptotic }\end{array}$ & Sang et al., 2000b \\
\hline
\end{tabular}

\section{Vaccarosides}

Vaccaroside

Common

(A-C)

structure

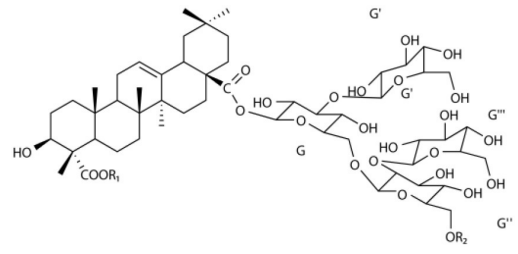

\begin{tabular}{lllll}
\hline Vaccaroside $\mathrm{A}$ & $\mathrm{C}_{54} \mathrm{H}_{86} \mathrm{O}_{25}$ & $\mathrm{R}_{1}=\mathrm{H}$ & Unknown \\
\hline Vaccaroside $\mathrm{B}$ & $\mathrm{C}_{60} \mathrm{H}_{94} \mathrm{O}_{29}$ & $\mathrm{R}_{1}=\mathrm{H}$ & $\mathrm{R}_{2}=\mathrm{H}$
\end{tabular}

\begin{tabular}{|c|c|c|c|c|}
\hline Vaccaroside C & $\mathrm{C}_{54} \mathrm{H}_{86} \mathrm{O}_{25}$ & $\mathrm{R}_{1}=\mathrm{glc} \quad \mathrm{R}_{2}=\mathrm{H}$ & Unknown & Koike et al., 1998 \\
\hline Vaccaroside D & $\mathrm{C}_{54} \mathrm{H}_{86} \mathrm{O}_{25}$ & & Unknown & Koike et al., 1998 \\
\hline
\end{tabular}

$\begin{array}{ll}\text { Vaccaroside } & \text { Common } \\ (\mathrm{E}-\mathrm{H}) & \text { structure }\end{array}$

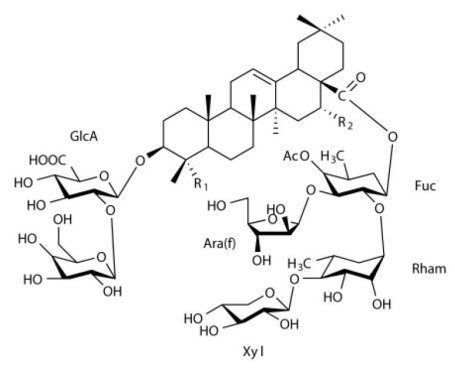

(Continued) 
TABLE 1 | Continued

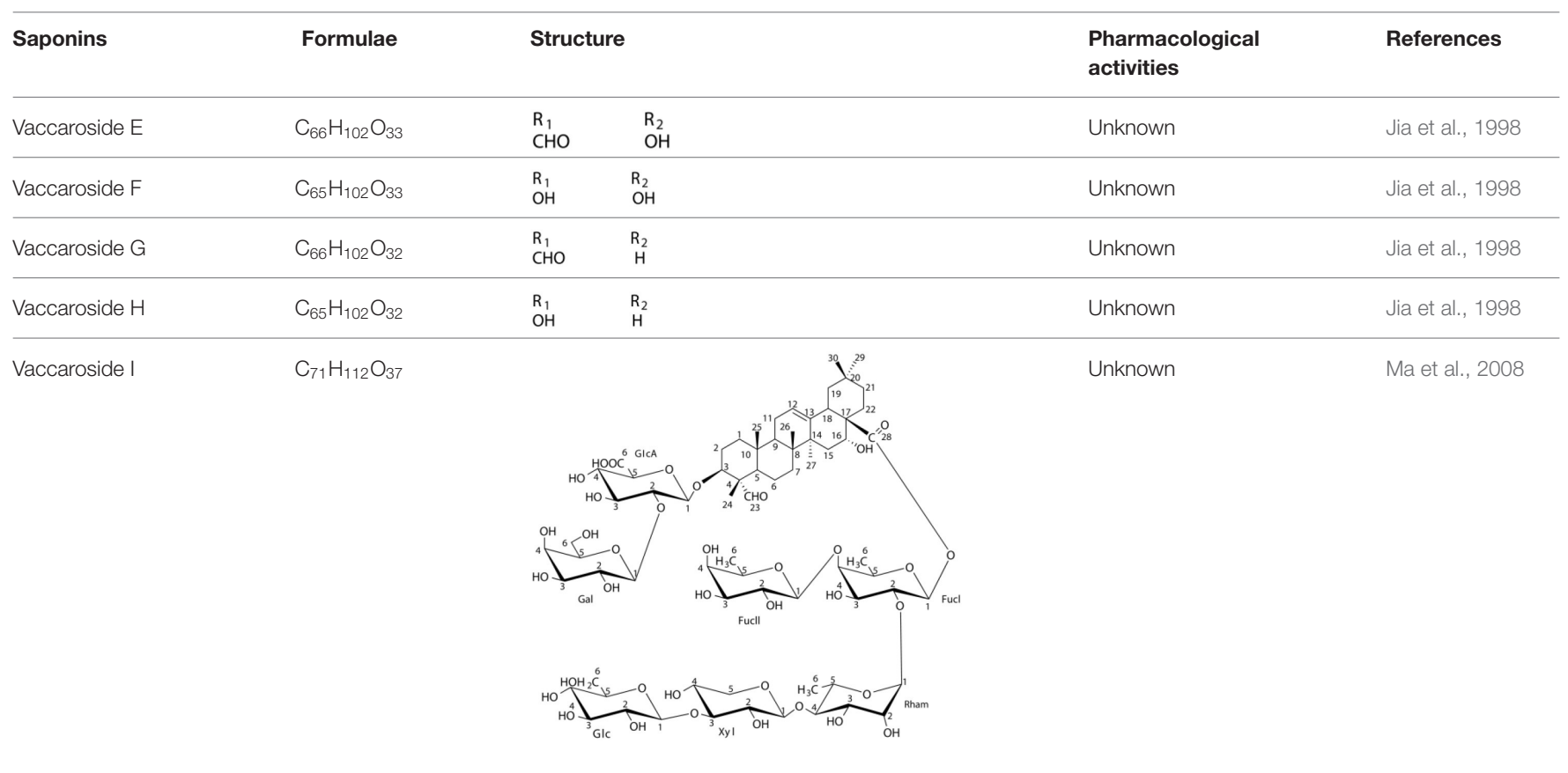

could significantly inhibit xylene-induced ear edema and reduce peritoneal capillary permeability and leukocyte infiltration induced by an intraperitoneal injection of acetic acid (Wang et al., 2015). Similar results were obtained in cells. For example, Sun et al. (2017) found that the Vaccaria hypaphorine concentration dependently downregulated the expression of inflammatory cytokine and inflammatory enzyme, and then counteracted the increased phosphorylation of nucleus transfer-related proteins that were induced by inflammation, thereby inhibiting a nuclear factor- (NF-) $\kappa$ B signaling pathway to exert its anti-inflammatory effect in lipopolysaccharide- (LPS-) stimulated Raw 264.7 cells. Osteoclasts are the only cells in the human body that undergo the bone resorption. Inhibiting the differentiation and formation of osteoclasts can effectively inhibit bone loss and osteolysis (Wei et al., 2018). A previous study suggested that Vaccaria hypaphorine inhibits the formation, differentiation, and resorption of osteoclast to attenuate inflammatory bone loss in LPS-treated mice by inhibiting an extracellular signal-regulated kinase (ERK), p38, a c-Jun N-terminal kinase (JNK), and an NF- $\kappa$ B p65 phosphorylation (Chen et al., 2018). However, Liu et al. (2019) demonstrated that Vaccaria inhibits formation and function of osteoclast in vivo and in vitro, as well as Ti particleinduced osteolysis. Chronic pelvic inflammatory disease (CPID) refers to chronic inflammation of the female internal organs, surrounding connective tissue, and pelvic peritoneum (Chen, 2012; Bu et al., 2015). Man Pen Fang (MPF), a Chinese herbal compound consisting of the whole plants of Thlaspi arvense L. (Cruciferae), Gleditsia sinensis Lam. (Fabaceae), Smilax china L. (Liliaceae), Euonymus alatus (Thunb.) Sieb. (Celastraceae), and the seeds of $V$. segetalis (Neck; Caryophyllaceae), was proven to be effective for treating CPID in the previous studies (Kim et al.,
2015; Li et al., 2016). In this formulation, V. segetalis (Neck) plays an important role because it has analgesic and anti-inflammatory properties, and activates blood circulation by dissipating blood stasis. In previous studies, Zhang et al. (2017) constructed a CPID mouse model (Tuffrey et al., 1992; Chen et al., 2008) and treated the animals with MPF. They revealed that MPF has a significant dose-dependent anti-inflammatory effect during the CPID treatment, and it also plays a positive role by decreasing the serum levels of inflammatory cytokines such as interleukin(IL-) 6, IL-10, tumor necrosis factor (TNF)- $\alpha$, and transforming growth factor (TGF)- $\beta$ (Zhang et al., 2017). Zhang et al. (2017) conducted mechanistic research on TCMs and provided a theoretical support for the use of MPF to treat CPID. Trichinosis is an infectious disease caused by parasites, and it poses a serious hazard to the pork industry and human health (Rostami et al., 2017). In the host, Trichinella activates inflammatory cells to overexpress cyclooxygenase-2 (COX-2; Othman et al., 2016) and other inflammatory factors. Xu et al. (2019) demonstrated that Vaccaria n-butanol extract (VNE) from the seeds of $V$. segetalis can significantly relieve the symptoms of Trichinella spiralis infection. However, VNE from the seeds of $V$. segetalis did not significantly and directly affect the viability of $T$. spiralis muscle larvae. The study suggested that the survival rate of $T$. spiralis muscle larvae did not differ between the control and VNE treatment. Moreover, VNE exerted anti-inflammatory effects by repressing the IL- $1 \beta$, IL- 6 , TNF- $\alpha$, and COX-2 expression in mice. Therefore, it was speculated that VNE is likely to exert its anti-inflammatory effect by reducing the inflammatory response in infected mice and exhibiting similar insecticidal effects to $T$. spiralis (Xu et al., 2019). Albendazole is commonly used to treat human trichinellosis. However, because of its clinical side effects, 
TABLE 2 | Cyclic peptides present in the seeds of $V$. segetalis.

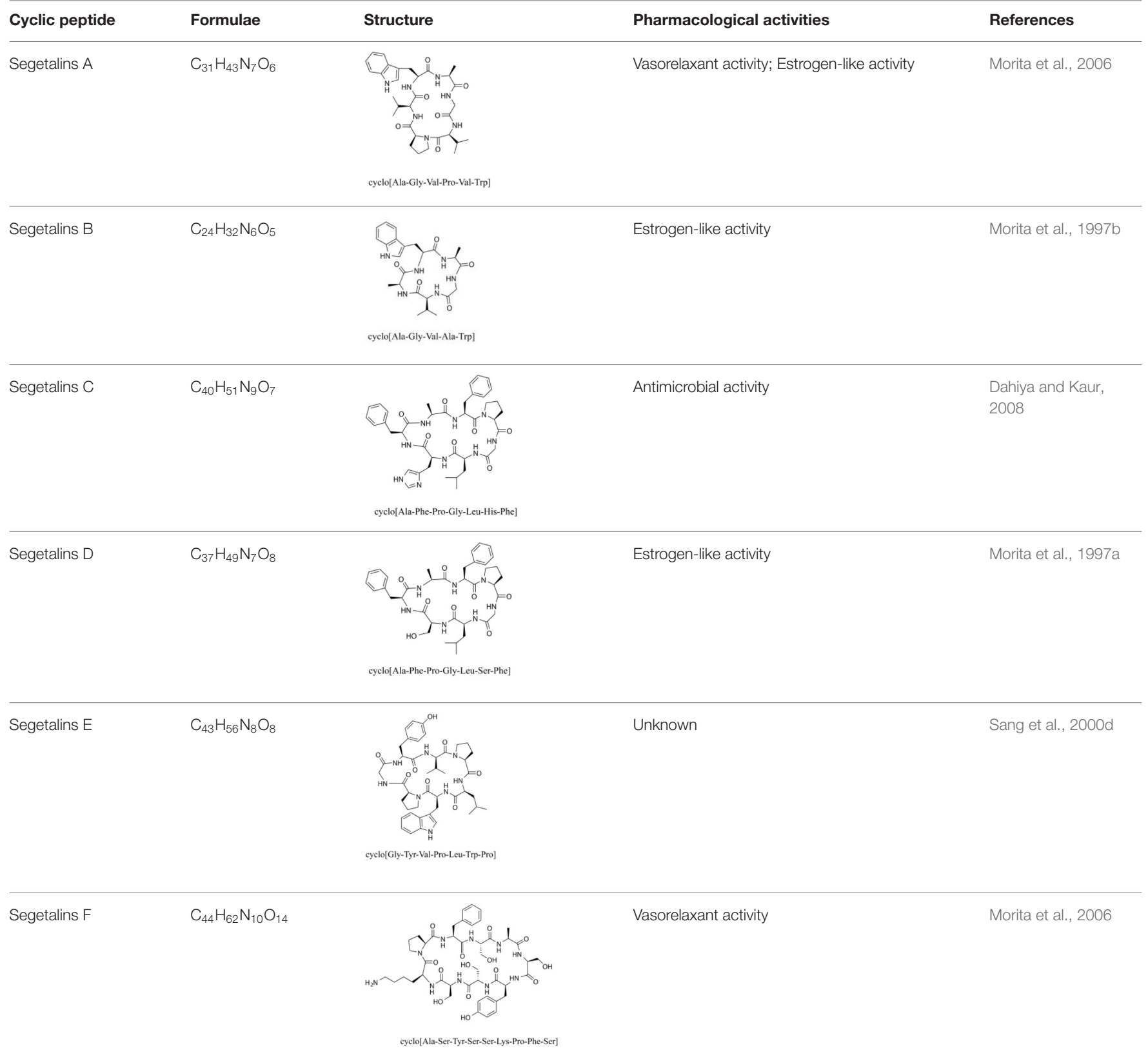

Segetalins $\mathrm{G}$




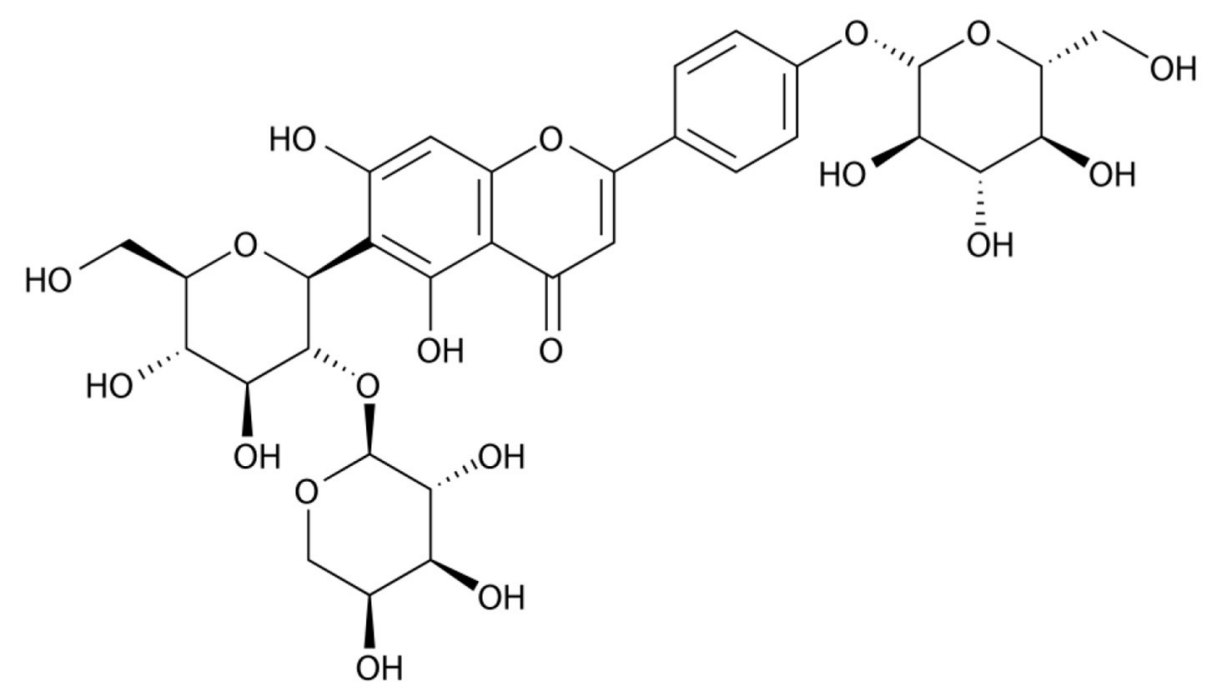

FIGURE 1 | Structure of vaccarin.

VNE may be an adjuvant to the existing drug. A recent study provided insights into the mechanism of the anti-inflammatory effects of $V$. segetalis. Mao found that crude polysaccharides from the seeds of $V$. segetalis (SVCP) can effectively prevent the urinary tract infections that are induced by uropathogenic Escherichia coli (UPEC) in 2020. SVCP-induced upregulation of IL- 6 and IL- 8 helps to eliminate bacteria in the urine, and does not cause tissue damage and acute pyelonephritis via the upregulation of pro-inflammatory cytokines. In addition, the authors found that the application of SVCP could upregulate the PIGR expression in rat kidneys, which was significantly suppressed by UPEC (Mao et al., 2020). This suggests that SVCP can prevent the infection caused by UPEC by stimulating an innate immunity of the kidneys. In addition, (Mao et al., 2021) explored the potential mechanism of SVCP in the treatment of kidney infections in a recent research study. The administration of SVCP upregulated the low expression of Cathelicidin family (LL-37 and CRAMP) in the UPEC-induced kidney infection model, and upregulated the expression of Toll-like receptors (TLRs). TLR agonists can stimulate the expression of cathelicidin (Liu et al., 2006; Vandamme et al., 2012). In summary, SVCP may increase the expression of cathelicidin by activating TLRS to protect the kidney from infection. This enriches the mechanism of action of SVCP.

Currently, antibiotics are the most widely used drugs to treat inflammation-related diseases. However, the long-term use of antibiotics in large quantities will lead to drug resistance and cause serious side effects in some patients, leading to treatment failures. The anti-inflammatory effect of $V$. segetalis provides new avenues for the treatment of inflammatory diseases.

\section{Anticancer Activity}

In 1971, Folkman (1971) first proposed the theory of tumor angiogenesis. Through an in-depth study of malignancies, the researchers found that angiogenesis is an important process in tumorigenesis and tumor development. Angiogenesis can be activated at different stages of tumor development. Currently, anti-angiogenic drugs represent a leading field in the development of new antitumor drugs (Viallard and Larrivee, 2017). The inhibition of angiogenesis has become a necessary strategy for antitumor therapy (D'Amato and Adamis, 1995; Folkman, 1995; Tímár et al., 2001). Continuous proliferation and migration of vascular endothelial cells are the primary steps in angiogenesis. During the neovascularization, endothelial cells first establish a cell-to-cell contact and then proliferate and migrate to a perivascular matrix where cellular connections are re-established and new vessels are formed (Carmeliet and Jain, 2000). Vascular endothelial cells can also secrete vascular growth factors to promote the proliferation of vascular endothelial cells and tumor cells. The inhibition of vascular endothelial cells can inhibit the proliferation of tumor cells and increase apoptosis in metastatic tumor cells. Therefore, anti-angiogenic therapy targeting vascular endothelial cells involved in the proliferation and migration can be an effective antitumor strategy.

Platelet-endothelial cell adhesion molecule-1 (PECAM-1), which is also known as CD31, is a key molecule of cell adhesion. In the process of neovascularization, CD31 is closely related to the movement of endothelial cells, and it may be involved in the signal transduction that is responsible for cell adhesion (Sun et al., 2000). CD31-blocking antibodies inhibit angiogenesis that is induced by cytokines and tumors in different animal models (Lertkiatmongkol et al., 2016).

Many studies have suggested that $V$. segetalis has anticancer and anti-angiogenic effects. We have summarized the pharmacological data and the effects of an herb (Table 3). The results illustrated that $V$. segetalis extract has anticancer effects in various cancer cells. V. segetalis extract reduced the expression of CD31 in peripheral endothelial cells and reduced the microvessel density in surrounding tissues. Further research revealed that $V$. segetalis water extract significantly inhibits the 
TABLE 3 | Anticancer activity of $V$. segetalis.

\begin{tabular}{|c|c|c|c|c|c|c|c|c|}
\hline & Model used & Plant part used & Extract type & Admin & Dosage/duration & Control & Results & References \\
\hline \multirow[t]{3}{*}{$\begin{array}{l}\text { Anti-angiogenesis and } \\
\text { anticancer }\end{array}$} & $\begin{array}{l}\text { In vivo. Mice, injection } \\
\text { of Lewis lung cancer } \\
\text { cells }\end{array}$ & $\begin{array}{l}\text { Seeds, Vaccaria } \\
\text { segetalis }\end{array}$ & $\begin{array}{l}\text { Seeds, decocted twice, } \\
\text { filtered, decompressed and } \\
\text { condensed into concretes, } \\
\text { and freeze-dried to powder }\end{array}$ & Per oral & $\begin{array}{l}\text { Mice were fed with the } \\
\text { solution }(100 \mu \mathrm{g} / \mathrm{mL}) \\
\text { prepared with dry } \\
\text { powder after the fourth } \\
\text { day of inoculation }\end{array}$ & $\begin{array}{l}\text { Baseline } \\
\text { control/Negative } \\
\text { control }\end{array}$ & $\begin{array}{l}\text { Vaccaria segetalis extract }(40 \mu \mathrm{g}) \text { reduced } \\
\text { tumors by } 58.3 \% \text {, reduced CD } 11 \\
\text { expression in peripheral endothelial cells, } \\
\text { and reduced the microvessel density in } \\
\text { surrounding tissues. } \\
\text { It indicated that the extract prevented } \\
\text { progress of established tumors and } \\
\text { reduced angiogenesis }\end{array}$ & $\begin{array}{l}\text { Feng et al., } \\
2012\end{array}$ \\
\hline & In vitro. MTT assay & $\begin{array}{l}\text { Seeds, Vaccaria } \\
\text { segetalis }\end{array}$ & $\begin{array}{l}\text { Seeds, decocted twice, } \\
\text { filtered, decompressed and } \\
\text { condensed into concretes, } \\
\text { and freeze-dried to powder }\end{array}$ & In vitro & $\begin{array}{l}\text { Different } \\
\text { concentrations }(\mu \mathrm{g} / \mathrm{ml})\end{array}$ & Negative control & $\begin{array}{l}\mathrm{IC}_{50}=50 \mu \mathrm{g} / \mathrm{mL} \\
\text { Vaccaria segetalis extract inhibited the } \\
\text { migration of HMECs in a dose-dependent } \\
\text { manner. It suggested that the extract can } \\
\text { inhibit the migration of vascular } \\
\text { endothelial cells }\end{array}$ & $\begin{array}{l}\text { Feng et al., } \\
2012\end{array}$ \\
\hline & $\begin{array}{l}\text { In vivo. CAM assay; } \\
\text { In vivo. Mice, injection } \\
\text { of Matrigels. }\end{array}$ & $\begin{array}{l}\text { Seeds, Vaccaria } \\
\text { segetalis }\end{array}$ & $\begin{array}{l}\text { Seeds, decocted twice, } \\
\text { filtered, decompressed and } \\
\text { condensed into concretes, } \\
\text { and freeze-dried to powder }\end{array}$ & $\begin{array}{l}\text { Injection; } \\
\text { Matrigels } \\
\text { mixed drugs }\end{array}$ & $\begin{array}{l}\text { Prepare the extract as } \\
(100 \mu \mathrm{g} / \mathrm{ml}) \text { and treat } \\
\text { with } 10 \mu \mathrm{L} ; 100 \mu \mathrm{L} \\
100 \mu \mathrm{g} / \mathrm{mL} \text { Vaccaria } \\
\text { segetalis extract }\end{array}$ & $\begin{array}{l}\text { Negative control; } \\
\text { Baseline } \\
\text { control/Positive } \\
\text { control/negative } \\
\text { control }\end{array}$ & $\begin{array}{l}\text { The new blood vessel formation in the } \\
\text { extract group was significantly reduced } \\
\text { The extract significantly reduced the } \\
\text { number of invasive endothelial cells in the } \\
\text { Matrigel plug and inhibited } \\
\text { microvessel formation }\end{array}$ & $\begin{array}{l}\text { Feng et al., } \\
2012\end{array}$ \\
\hline $\begin{array}{l}\text { Anti-angiogenesis and } \\
\text { Anticancer }\end{array}$ & $\begin{array}{l}\text { In vivo. Mice, } \\
\text { subcutaneous injection } \\
\text { of } \mathrm{H} 22 \text { cells for solid } \\
\text { carcinoma model }\end{array}$ & $\begin{array}{l}\text { Seeds, Vaccaria } \\
\text { segetalis }\end{array}$ & $\begin{array}{l}\text { Vaccaria segetalis } 70 \% \\
\text { ethanol extract, purified by } \\
\text { D-101 resin column. }\end{array}$ & $\begin{array}{l}\text { Intragastric } \\
\text { administrate }\end{array}$ & $\begin{array}{l}\text { Treatment group ( } 1 \text {, } \\
2.5 \text {, and } 5 \mathrm{mg} / \mathrm{kg})\end{array}$ & $\begin{array}{l}\text { Negative } \\
\text { control/three } \\
\text { treatment groups }\end{array}$ & $\begin{array}{l}\text { The results suggested that mouse body } \\
\text { weight increased, CD31 expression in } \\
\text { tumor vessels decreased, and the } \\
\text { apoptosis in tumor cells and vascular } \\
\text { endothelial cells was induced. It implied } \\
\text { that the use of Vaccaria segetalis } \\
\text { improved the health of mice, and had the } \\
\text { effect of inhibiting tumor growth and } \\
\text { anti-angiogenesis }\end{array}$ & $\begin{array}{l}\text { Gao Y. Y. et al., } \\
2010\end{array}$ \\
\hline Anticancer & $\begin{array}{l}\text { In vitro. Cancer cell line } \\
\text { (A549, MCF-7, PC-3, } \\
\text { LNCaP) } \\
\text { Normal human } \\
\text { mammary epithelial } \\
\text { cells (HMECs); } \\
\text { Antiproliferative assay }\end{array}$ & $\begin{array}{l}\text { Seeds, Vaccaria } \\
\text { segetalis }\end{array}$ & $\begin{array}{l}\text { Vaccaria segetalis water } \\
\text { extract }\end{array}$ & In vitro. & $\begin{array}{l}\text { Different concentration } \\
(\mu \mathrm{g} / \mathrm{ml})\end{array}$ & Treatment groups & $\begin{array}{l}\text { The result suggested that Vaccaria } \\
\text { segetalis had anticancer effects in vitro } \\
\text { and these effects are markedly greater in } \\
\text { various cancer cells } \\
\text { This experiment indicated that Vaccaria } \\
\text { segetalis water extract can inhibit } \\
\text { proliferation of cancer cell lines }\end{array}$ & $\begin{array}{l}\text { Mark et al., } \\
2005\end{array}$ \\
\hline Anti-angiogenesis & $\begin{array}{l}\text { In vivo. Mice, injection } \\
\text { of Matrigels. }\end{array}$ & $\begin{array}{l}\text { Seeds, Vaccaria } \\
\text { segetalis }\end{array}$ & $\begin{array}{l}\text { Seeds, decocted twice, } \\
\text { filtered, decompressed and } \\
\text { condensed into concretes, } \\
\text { and freeze-dried to powder }\end{array}$ & $\begin{array}{l}\text { Matrigels } \\
\text { mixed drugs }\end{array}$ & $0.1 \mathrm{~g}$ extract & $\begin{array}{l}\text { Negative } \\
\text { control/Positive } \\
\text { control }\end{array}$ & $\begin{array}{l}\text { Reduction of endothelial cells and } \\
\text { decrease of the formation of abundant } \\
\text { microvessels induced by basic fibroblast } \\
\text { growth factor (bFGF) }\end{array}$ & $\begin{array}{l}\text { Passaniti et al., } \\
1992\end{array}$ \\
\hline $\begin{array}{l}\text { Anticancer by } \\
\text { promoting apoptosis of } \\
\text { cancer cells }\end{array}$ & $\begin{array}{l}\text { In vitro. MTT } \\
\text { assay/DNA } \\
\text { fragmentation; In vivo. } \\
\text { Mice, HepG2 xenograft } \\
\text { Kunming }\end{array}$ & $\begin{array}{l}\text { Seeds, Vaccaria } \\
\text { segetalis }\end{array}$ & $\begin{array}{l}\text { Segetoside I, standardized } \\
\text { by crude ethanol extract, } \\
\mathrm{CH} 2 \mathrm{Cl} 2 / \mathrm{MeOH} \text { mixture, } \\
\mathrm{MeOH}-\mathrm{H} 2 \mathrm{O} \text { (RP-8 and } \\
\mathrm{RP}-18 \text { columns) gradient } \\
\text { elution }\end{array}$ & $\begin{array}{l}\text { In vitro; } \\
\text { Intraperitoneal } \\
\text { injection }\end{array}$ & $\begin{array}{l}\text { Different concentration } \\
\text { of segetoside I; } \\
\text { Segetoside I }(1.25,2.5 \text {, } \\
5 \mathrm{mg} / \mathrm{kg})\end{array}$ & $\begin{array}{l}\text { Negative } \\
\text { control/Positive } \\
\text { control }\end{array}$ & $\begin{array}{l}\mathrm{IC}_{50}=8.62 \mu \mathrm{M} \text {; Dose-dependent DNA } \\
\text { fragmentation and increase Bax/Bcl-2 } \\
\text { expressions by Segetoside I ( } 0.82,8.2 \text {, } \\
82 \mu \mathrm{M}) \text {; Dose-dependent inhibition of } \\
\text { tumor growth with segetoside I }\end{array}$ & $\begin{array}{l}\text { Firempong } \\
\text { et al., } 2016\end{array}$ \\
\hline
\end{tabular}

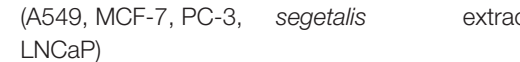

Mice were fed with the powder after the fourth indicated that the extract prevented stablished tumors an

ve contro $00 \mu \mathrm{g} / \mathrm{mL}$ Vaccaria endothelial cells was induced. It implied caria segetalls anti-angiogenesis cancer cells

fragmentation and increase Bax/Bcl-2

$82 \mu \mathrm{M})$ : Dose-dependent inhibition of

tumor growth with segetoside 
proliferation and migration of human mammary epithelial cells (HMECs) in a concentration-dependent manner. This indicates that the main function of $V$. segetalis extract is to block the proliferation and migration of endothelial cells. $V$. segetalis has anticancer effects in vitro, and these effects are markedly enhanced in select cancer cells. Other studies demonstrated that $V$. segetalis extract can decrease the formation of abundant microvessels, which was induced by a basic fibroblast growth factor (bFGF). bFGF is found in almost all mesoderm-derived and neuroectoderm-derived tissues as well as the tumors derived from these tissues. bFGF has been shown to have a mitogenic, chemotactic, and angiogenic activity, which promotes cell growth, differentiation, and motility (Finzel et al., 1984). By analyzing a few literature studies, we determined that $V$. segetalis extract can reduce the formation and expansion of tumors by suppressing the formation of abundant microvessels and preventing the proliferation and migration of epithelial cells. Additionally, $V$. segetalis extract will likely to inhibit angiogenesis that is induced by cytokines and tumors by reducing the expression of $\mathrm{CD} 31$. Inhibiting angiogenesis was also shown, which often leads to the reduction of tumors; thus, angiogenesis is a critical prerequisite for the tumor formation, and the anti-angiogenic effect of $V$. segetalis provides a new strategy for treating tumors. Anti-angiogenic drugs that are commonly used in clinical practice include vascular endothelial growth factor (VEGF) monoclonal antibodies (Cao et al., 2015), thalidomide (Bladé et al., 2001), and vandetanib (Vitagliano et al., 2010), but these drugs can cause serious side effects and increase medical costs. The discovery and study of anti-angiogenic effects of $V$. segetalis have provided new directions for the development of anticancer drugs in the future.

Tumors are caused by the acceleration of cell proliferation and suppression of apoptosis. Tumor treatment can also be accomplished by inducing apoptosis in tumor cells. Many studies support the apoptotic effect of $V$. segetalis in cancer cells. The results identified the $V$. segetalis compounds that have significant antitumor effects, and these are triterpenoid saponins (segetoside $\mathrm{H}$ and segetoside I) and some unknown compounds (Gao Y. Y. et al., 2010; Balsevich et al., 2012). Segetosides H and I, which are isolated from $V$. segetalis, have significant anticancer effects (Table 3; Yun et al., 1998). Previous studies demonstrated that segetoside I can induce DNA fragmentation and the upregulation of apoptosis-related genes, suggesting that the activation of apoptotic signaling events may have been initiated. Segetoside I also suppressed hepatic tumor growth in mice with virtually no cytotoxicity, and prolonged animal survival (Firempong et al., 2016), and thus, it may be an effective candidate for treating tumors. These results suggest that segetosides $\mathrm{H}$ and I can induce cancer cell apoptosis by activating apoptotic pathways to prevent the development of cancer, which may make them valuable antitumor chemotherapeutics.

In summary, we propose that $V$. segetalis extract can exert its anticancer effects in two ways. First, the extract can inhibit the tumor growth and angiogenesis around the tumor and second, it can activate apoptosis pathways in cancer cells. To study the mechanism of the anticancer action of $V$. segetalis in the future, we should focus on angiogenesis-related and apoptosis-related pathways. Although $V$. segetalis has been used as traditional Chinese herbal medicine for more than 2000 years, its anticancer effect has been newly proposed in recent years and the current experiments remain in the preclinical stage, including cell and animal models. Deeper mechanism studies and more expansive clinical data are needed to prove and support medication methods, dosages, and other variables. Thus, much work remains before $V$. segetalis or its extracts can be used to treat patients with cancer.

\section{Inhibition of Apoptosis}

Apoptosis is also known as a programmed cell death. Despite its ability to induce apoptosis in tumor cells as mentioned previously, $V$. segetalis can inhibit apoptosis that is caused by apoptotic factors in normal cells. Vaccarin was shown to exert a potential protective effect in $\mathrm{H}_{2} \mathrm{O}_{2}$-injured human EA.hy926 endothelial cells by inhibiting the Notch signaling pathway and downregulating caspase-3, which has a dominant role in the execution of the apoptotic process. Caspase- 3 activation is a central link in apoptosis (Xie et al., 2015). $\mathrm{H}_{2} \mathrm{O}_{2}$ is often used to develop a validation model, and it stimulates cells to produce reactive oxygen species (ROS) (Schieber and Chandel, 2014). Previous studies revealed that the ROS production and apoptosis can occur simultaneously (Corbacho et al., 2002). Further studies illustrated that vaccarin can suppress a high glucose-induced damage in EA.hy926 cells, which was shown by improved cell viability and migratory ability, and this treatment effectively suppressed the caspase-3 overexpression (Qiu et al., 2016).

The abovementioned studies demonstrated that vaccarin, which is an active ingredient of $V$. segetalis, can downregulate the apoptotic gene expression that is induced by apoptotic factors, thereby inhibiting apoptosis. We can imagine a clinical role for vaccarin as an antioxidant based on its ability to prevent $\mathrm{H}_{2} \mathrm{O}_{2}$-induced apoptosis, specifically as a daily supplement.

\section{Dilation of Blood Vessels}

Vasodilators can be used to treat hypertension, coronary atherosclerotic heart disease, angina pectoris, and cerebrovascular sclerosis. $V$. segetalis is often used to treat headache, hypertension, asthmatic pneumonia, and other diseases. Because of its vasodilatory effects, V. segetalis (Neck) Garcke decoction had a significant concentration-dependent relaxing effect on the norepinephrine-induced precontraction of the rabbit aortic smooth muscle. After removing endothelial cells, the relaxation effect of $V$. segetalis (Neck) Garcke on noradrenaline-precontracted arterial rings was significantly decreased (Hua'e et al., 2007). Morita et al. (1997a) found that segetalins $\mathrm{A}, \mathrm{D}, \mathrm{F}, \mathrm{G}$, and $\mathrm{H}$ exhibited vasodilatory activity against norepinephrine-induced aortic contraction in rats, and among these, segetalins $\mathrm{G}$ and $\mathrm{H}$ had the strongest diastolic activity. In addition, a study by Jing et al. (2007) reported the same relaxation in aortic ring samples that lacked an endothelium. The volatile oil in $V$. segetalis may be responsible for this function (Shiva Kumar et al., 2017). The specific mechanisms of segetalin action on vasodilation and contractile activity require further investigation. Previously, we explained that TCM often uses the seeds of $V$. segetalis to mechanically stimulate auricular points 
to assist in the treatment of hypertension. In addition to the unique characteristics of its seeds, we speculate that it is also possible that the volatile oil of $V$. segetalis could enter the body through the skin at the ear point. (Morita et al., 2006) found that the segetalins in $V$. segetalis extract have a vasodilatory activity. Although the vasodilatory activity of segetalins has been reported in animal models, there are no clinical data to date. However, the evidence points to a new strategy for the treatment of vasoconstriction-related diseases.

\section{Promotion of Lactation}

A recent study indicated that the use of $V$. segetalis during breastfeeding to promote breast milk is common in Macau (Zheng et al., 2020). Many studies have revealed that $V$. segetalis, Leonurus, and Astragalus can significantly promote lactation in female rats (Baoming and Anshan, 2007). Although this treatment remains in use, the mechanism by which $V$. segetalis induces lactation is unclear.

One of the primary ingredients in $V$. segetalis is vaccarin (Jia et al., 1998), which promotes the proliferation of mammary epithelial cells and enhances their secretory function (Leonoudakis et al., 2010). Mammary epithelial cells are the breast biological generators that synthesize and secrete milk. The number and activity of mammary epithelial cells are closely related to the lactation performance of livestock (Planas-Silva et al., 2006). The latest research has enriched the lactation mechanism of Vaccarin. Vaccarin and PRL have similar effects in stimulating the proliferation of breast epithelial cells and enhancing their secretory function, the expression of Cylin D1, the phosphorylation of mechanistic target of rapamycin (mTOR), and the regulation of the expression of a sterol regulatory element binding protein 1c (SREBP-1c). In addition, Vaccarin can promote the expression of PRL receptors. In summary, Vaccarin can promote the breast epithelial cell proliferation and enhance its secretion ability via the PRL receptor-PI3K-Cyclin D1/SREBP-1c/mTOR signaling pathways (Yu et al., 2020). JAK2 is important for the PRL signal transduction and normal breast tissue development, and STAT5a is necessary for the breast development (Gass et al., 2003). $\beta$-casein is an important milk protein, and its secretion level reflects the lactation ability of breast epithelial cells to a certain extent. Gao X. J. et al. (2010) found that the dibutyl phthalate (DBP) injection can increase the milk production in cows. Liu et al. (2010) found that DBP could significantly increase the proliferation and viability of mammary epithelial cells in dairy cows. It was also found that DBP could increase the $\beta$-casein expression and lactose secretion in breast epithelial cells (Tong et al., 2013). In addition, Tong et al. found that DBP from $V$. segetalis can promote lactation and the proliferation of breast epithelial cells and activate a JAK-STAT5-signaling pathway by increasing the STAT5 phosphorylation levels (Tong et al., 2011). These studies demonstrated that DBP has estrogenic activity, and that it can activate a lactation-signaling pathway and promote lactation by regulating the milk protein, lactose, and milk fat synthesis. However, as a highly toxic substance, the dosage and application of DBP require more theoretical research and experimental support.
The low postpartum lactation ability of mammals is mainly attributable to the insufficient activation of the relevant endocrine system in the body, preventing mammary glands from producing milk normally and hindering milk excretion. Chinese herbal medicine can promote lactation by regulating the metabolism of postpartum mammals and increasing endocrine levels in vivo. Kleinberg and Ruan (2008) found that V. segetalis increased the content of growth hormones (GHs) and PRL in serum from dairy cows, which in turn promoted the breast development and improved the lactation performance. Jun-Xian et al. (2013) used $V$. segetalis water extract, which had a similar effect to estrogen and PRL, and its components could bind to an estrogen receptor to activate a STAT5-signaling pathway, thereby promoting the P-STAT5 expression and milk protein synthesis. Bryant (2009) found that the PRL promoter transcription and PRL synthesis can be induced by stimulating the estrogen receptor system and pituitary transcription factor Pit-1. PRL controls the regulation of milk protein at the translational level, thereby promoting the synthesis of milk proteins. Another study reported similar results and suggested that $V$. segetalis has a specific estrogen-like effect; specifically, its components can bind to an estrogen receptor, and thereby promoting the synthesis of PRL (Itokawa et al., 1995).

Based on these findings, we concluded that the stimulatory effects of $V$. segetalis on the production of milk occur through DBP and that DBP has PRL-like effects. In addition, a few studies have found that the other substances in $V$. segetalis have estrogenlike effects, and estrogen-like active ingredients can bind with estrogen receptors to promote the synthesis of PRL. This implies a synergy between the actions of various substances in $V$. segetalis. These results provide new ideas for future studies on $V$. segetalis.

\section{Estrogen-Like Action}

Many studies have revealed the estrogen-like effect of $V$. segetalis. Pakoussi et al. (2018) found that phytoestrogens enhance uterine contractions. Morita et al. (1997c) discovered vaccaroid $\mathrm{A}$ in $V$. segetalis and found that it has a role in promoting uterine contractions. Moreover, the research has illustrated that segetalins $\mathrm{A}, \mathrm{B}, \mathrm{G}$, and $\mathrm{H}$ are cyclic hexapeptides and pentapeptides with estrogenic activity in ovariectomized rats (Morita et al., 1993, 1995; Yun et al., 1997). Segetalins are the only natural cyclic peptides that were reported to have estrogenic activity. When they are digested into acyclic segetalins by enzymes, they lose their activity, indicating that their conformation plays an important role in their function (Morita et al., 1997a). A study found that segetalins $\mathrm{G}$ and $\mathrm{H}$ at a dose of $2.5 \mathrm{mg} / \mathrm{kg}$ significantly increased uterine weight vs. the control $(p<0.01)$ in ovariectomized rats that did not receive the estrogen supplementation for 2 weeks (Yun et al., 1997). Itokawa et al. (1995) applied segetalins A and B to ovariectomized rats for 14 consecutive days and observed similar effects to those of segetalins $G$ and $H$, verifying that segetalins $A, B, G$, and $\mathrm{H}$ have estrogen-like effects. Ovariectomy-induced bone loss in rats and postmenopausal bone loss in women share many similar features, and the clinical symptoms are often treated by $17 \beta$-estradiol supplementation (Kalu, 1991). To study the estrogen-like activity of $V$. segetalis and facilitate its future clinical applications, Shih et al. (2009) constructed an ovariectomized 
TABLE 4 | Cytotoxic activity (IC50, mM) of compounds 1-6.

\begin{tabular}{|c|c|c|c|c|c|c|c|c|}
\hline Cell lines & 1 & 2 & 3 & 4 & 5 & 6 & Topotecan & Docetaxel \\
\hline LNcap & 3.6 & 3.4 & 2.5 & 4.2 & 12.9 & 1.2 & 0.053 & \\
\hline A-549 & 1.0 & 3.0 & 11.0 & 1.0 & 7.2 & 0.4 & & $<0.01$ \\
\hline P-388 & 0.8 & 9.4 & 0.7 & 3.7 & 1.6 & 0.1 & & $<0.01$ \\
\hline
\end{tabular}

Compound 1, vaccaroside I; Compound 2, vaccaroside E; Compound 3, vaccaroside G; Compound 4, vaccaroside B; Compound 5, segetoside H; Compound 6, segetoside I. LNCaP, human prostate cancer cell line; A549, human lung cancer cell line; P388, mouse leukemia cell line.

Topotecan and docetaxel were used as positive controls.

rat model to simulate postmenopausal bone loss in women. In the ovariectomized group, the calcium content of the femur and the fourth lumbar vertebra was significantly reduced, whereas these effects were alleviated by the supplementation with $17 \beta$ estradiol or $V$. segetalis extract. $V$. segetalis extract does not cause side effects such as uterine or vaginal hypertrophy. This provides a new direction for the treatment of osteoporosis. Moreover, because of its estrogen-like activity, $V$. segetalis can be used as an alternative to estrogen for people with allergies to synthetic estrogens. In addition, $V$. segetalis can avoid the side effects of estrogen supplementation.

\section{TOXICOLOGY RESEARCH}

Several toxicological studies related to $V$. segetalis have been conducted. In one study, $V$. segetalis extract obtained via a reflux with $75 \%$ ethanol was used to treat mice. The minimum toxic amount of $V$. segetalis extract in mice was $100 \mathrm{mg} / \mathrm{kg}$, and the minimum lethal dose was $1,500 \mathrm{mg} / \mathrm{kg}$. $V$. segetalis extract was more toxic to the heart and kidneys of mice at $1,000 \mathrm{mg} / \mathrm{kg}$ (approximately lethal dose) than lung, and there was no serious functional damage in mice treated with $200 \mathrm{mg} / \mathrm{kg}$ of $V$. segetalis extract. Therefore, $V$. segetalis shows a good safety profile, and it could be a promising therapeutic modality (Gao et al., 2013).

Segetoside $I$ is an extract of $V$. segetalis, and it has been a focus of research. One study showed that intraperitoneal segetoside I in mice had an LD50 (median lethal dose) of $14.5 \mathrm{mg} / \mathrm{kg}$ (Firempong et al., 2016). The mice were treated with segetoside I at different concentrations and sacrificed after 14 days, and their respective organ coefficients were determined. The tissue coefficients of the heart, liver, and kidney did not change significantly, whereas the tissue coefficient of the spleen increased with increasing doses of segetoside I. The spleen coefficient was significantly improved by segetoside I at the concentration of $1.25,2.5$, and $5 \mathrm{mg} / \mathrm{kg}$. This demonstrated that segetoside I did not significantly affect the body weight of mice, but that it damaged the spleen at doses exceeding $5 \mathrm{mg} / \mathrm{kg}$. In addition, the studies have explored the cytotoxic effects of different extracts of $V$. segetalis in different cells, and IC50 was obtained (Table 4; Ma et al., 2008).

In a previous study, it was mentioned that $V$. segetalis has an anti-inflammatory effect, but at the same time it has an estrogenlike effect, which also leads to certain side effects. Overdose of estrogen by men who have not entered puberty will cause the secondary sex characteristics of men to not appear but the second sex characteristics of women; excessive estrogen in puberty men will cause a gradual decline of the second sex characteristics of men, in addition to causing endocrine disorders, obesity, and even affect fertility (Kabir et al., 2015). This has led to a clinical application of Wang Buliuxing more oriented to females, and whether Wang Buliuxing can be used for the treatment of males and the applied dosage need more literature support. In addition, the anti-inflammatory effect of Wang Buliu Xing may hide an inflammatory process caused by the microorganism infection, which may lead to an aggravation of the infection, and thus may not fundamentally solve the problem.

Taken together, the toxicological information on $V$. segetalis remains extremely limited, and further research is required to determine the extraction, purification, and application of the active ingredients of $V$. segetalis.

\section{CONCLUSION}

$V$. segetalis is a plant used in traditional Chinese herbal medicine that occupies an extremely important position in the Chinese medicine theory. With an increasing amount of research on the active ingredients of $V$. segetalis, $V$. segetalis could be used with modern medicine to treat blood strangury, lactation deficiencies, and chylorrhea. $V$. segetalis can also be used to treat hypertension, headache, and gallstones through its unique ability to physically stimulate the corresponding acupuncture points on the ear or body. This article has provided in detail the chemical and pharmacological properties of $V$. segetalis and summarized the recent literature studies. The main ingredients in $V$. segetalis include flavonoids, cyclic peptides, saponins, and polysaccharides, but several active substances have not been identified, indicating the need for a more systematic phytochemical research. In terms of its pharmacological effects, $V$. segetalis has anti-inflammatory, anti-angiogenic, anticancer, anti-apoptosis, and estrogenic effects, dilates blood vessels, and promotes lactation. Many diseases are treated poorly using modern medicine, and traditional and complementary medicine can provide new treatment modalities for these diseases.

Although substantial research has been conducted on $V$. segetalis, many unknown elements in $V$. segetalis remain. In addition, some studies used hydroalcoholic crude extracts instead of the pure active ingredients of $V$. segetalis as the experimental objects. We speculate that hydroalcoholic crude extracts are used because the extraction process for the active ingredients of $V$. segetalis is more complicated. In addition, we found that $V$. 
segetalis crude extracts and some effective active ingredients also have anticancer effects that have not been mentioned in clinical applications, thereby further enhancing the significance of $V$. segetalis in modern research and providing new directions of future research.

Future research on $V$. segetalis should specifically focus on the four issues that are described below. First, we should continue to explore the unknown elements in V. segetalis. Second, the processes for extracting the effective active substances of $V$. segetalis should be further improved. Third, the mechanisms of the anti-inflammatory, anticancer, and anti-apoptotic effects of $V$. segetalis should be further elucidated. Finally, more research on the pharmacology and toxicology is needed to provide additional evidence for clinical applications.

\section{AUTHOR CONTRIBUTIONS}

CL, XZ, and MT conceptualized the study. MT, YH, XW, TC, $\mathrm{CY}, \mathrm{NW}, \mathrm{ZZ}$, and BZ investigated the study. MT wrote original

\section{REFERENCES}

Aswad, M., Rayan, M., Abu-Lafi, S., Falah, M., Raiyn, J., Abdallah, Z., et al. (2018). Nature is the best source of anti-inflammatory drugs: indexing natural products for their anti-inflammatory bioactivity. Inflamm. Res. 67, 67-75. doi: 10.1007/s00011-017-1096-5

Balsevich, J. J., Ramirez-Erosa, I., Hickie, R. A., Dunlop, D. M., Bishop, G. G., and Deibert, L. K. (2012). Antiproliferative activity of Saponaria vaccaria constituents and related compounds. Fitoterapia 83, 170-181. doi: 10.1016/j.fitote.2011.10.010

Banno, N., Akihisa, T., Tokuda, H., Yasukawa, K., Taguchi, Y., Akazawa, H., et al. (2005). Anti-inflammatory and antitumor-promoting effects of the triterpene acids from the leaves of Eriobotrya japonica. Biol. Pharm. Bull. 28, 1995-1999. doi: 10.1248/bpb.28.1995

Baoming, S., and Anshan, S. (2007). Effects of Chinese herbs on lactation of rat and performance of offspring. J. North. Agric. Univer. 14, 22-26. doi: CNKI:SUN:DBYN.0.2007-01-006

Bernard, P., Scior, T., Didier, B., Hibert, M., and Berthon, J. Y. (2001). Ethnopharmacology and bioinformatic combination for leads discovery: application to phospholipase A(2) inhibitors. Phytochemistry 58, 865-874. doi: 10.1016/S0031-9422(01)00312-0

Bladé, J., Esteve, J., Rosi?ol, L., Perales, M., Montoto, S., Tuset, M., et al. (2001). Thalidomide in refractory and relapsing multiple myeloma. Semin. Oncol. 28, 588-592. doi: 10.1016/S0093-7754(01)90029-6

Bozak, K. R., Yu, H., Sirevg, R., and Christoffersen, R. E. (1990). Sequence analysis of ripening-related cytochrome P-450 cDNAs from avocado fruit. Proc. Natl. Acad. Sci. U.S.A. 87, 3904-3908. doi: 10.1073/pnas.87.10.3904

Bryant, W. (2009). Environmental estrogens stimulate gene transcription in the prolactin promoter. Int. J. Biol. 2, 35-43. doi: 10.5539/ijb.v2n1p35

Bu, X., Liu, Y., Lu, Q., and Jin, Z. (2015). Effects of “danzhi decoction” on chronic pelvic pain, hemodynamics, and proinflammatory factors in the murine model of sequelae of pelvic inflammatory disease. Evid. Based Complement. Alternat. Med. 2015:547251. doi: 10.1155/2015/547251

Cao, R., Zhang, S., Ma, D., and Hu, L. (2015). A multi-center randomized phase II clinical study of bevacizumab plus irinotecan, 5-fluorouracil, and leucovorin (FOLFIRI) compared with FOLFIRI alone as second-line treatment for Chinese patients with metastatic colorectal cancer. Med. Oncol. 32:325. doi: 10.1007/s12032-014-0325-9

Carmeliet, P., and Jain, R. K. (2000). Angiogenesis in cancer and other diseases. Nature 407, 249-257. doi: 10.1038/35025220

Chen, H., Guo, T., Wang, D., and Qin, R. (2018). Vaccaria hypaphorine impairs RANKL-induced osteoclastogenesis by inhibition of ERK, p38, JNK and NF-кB draft preparation. CL and XZ helped in writing and editing the review. All authors contributed to the article and approved the submitted version.

\section{FUNDING}

This work was supported by the National Key Research and Development Program of China (Grant No. 2016YFD0500503); Jilin Key Programs for Science and Technology Development (Grant Nos. 20170204039NY and 20190301008NY); Cooperation Project of Jilin Province and Jilin University (Grant No. SXGJXX2017-11); and the Jilin Provincial Department of Education Project (Grant No. JJKH20190176KJ).

\section{ACKNOWLEDGMENTS}

We thank Liwen Bianji, Edanz Editing China (www.liwenbianji.cn/ac), for editing the English text of a draft of this manuscript. pathway and prevents inflammatory bone loss in mice. Biomed. Pharmacother. 97, 1155-1163. doi: 10.1016/j.biopha.2017.11.044

Chen, K. J. (2012). Blood stasis syndrome and its treatment with activating blood circulation to remove blood stasis therapy. Chin. J. Integrat. Med. 18, 891-896. doi: 10.1007/s11655-012-1291-5

Chen, Y., Liu, Q., Chen, Y., Huang, W., Jin, B., Ding, Z., et al. (2017). Study on hypoglycemic effects of total flavonoid aglycon from leaves of Carya cathayensis. Chin. Arch. Tradit. Chin. Med. 35, 2033-2035. doi: CNKI:SUN:ZYHS.0.2017-08-028

Chen, Y., Tian, L., Wang, X., and Wang, C. X. (2008). Drug particles of FUYANNING to chronic pelvic inflammatory disease model of the impact of rats' IL-2 IL-6. Chin. Arch. Tradit. Chin. Med.

Choi, D. W., Jung, J. D., Ha, Y. I., Park, H. W., Dong, S. I., Chung, H. J., et al. (2005). Analysis of transcripts in methyl jasmonate-treated ginseng hairy roots to identify genes involved in the biosynthesis of ginsenosides and other secondary metabolites. Plant Cell Rep. 23, 557-566. doi: 10.1007/s00299-004-0845-4

Corbacho, A. M., Martinez De La Escalera, G., and Clapp, C. (2002). Roles of prolactin and related members of the prolactin/growth hormone/placental lactogen family in angiogenesis. J. Endocrinol. 173, 219-238. doi: 10.1677/joe.0.1730219

Dahiya, R., and Dahiya, S. (2021). Natural cyclic polypeptides as vital phytochemical constituents from seeds of selected medicinal plants. Arch. Pharm. Chem. Life Sci. 354:e2000446. doi: 10.1002/ardp.2020 00446

Dahiya, R., and Kaur, K. (2008). Synthesis and pharmacological investigation of segetalin $\mathrm{C}$ as a novel antifungal and cytotoxic agent. Arzneimittelforschung 58, 29-34. doi: 10.1055/s-0031-1296463

D'Amato, R. J., and Adamis, A. P. (1995). Angiogenesis inhibition in age-related macular degeneration. Ophthalmology 102, 1261-1262. doi: 10.1016/S0161-6420(95)30876-7

Feng, L., Zhang, X., Hua, H., Qiu, L., Zhang, L., and Lv, Z. (2012). Vaccaria segetalis extract can inhibit angiogenesis. Asian Biomed. 6, 683-692. doi: 10.5372/1905-7415.0605.108

Finzel, B. C., Poulos, T. L., and Kraut, J. (1984). Crystal structure of yeast cytochrome c peroxidase refined at 1.7-A resolution. J. Biol. Chem. 259, 13027-13036. doi: 10.1016/S0021-9258(18)90651-4

Firempong, C. K., Zhang, H. Y., Wang, Y., Chen, J., Cao, X., Deng, W., et al. (2016). Segetoside I, a plant-derived bisdesmosidic saponin, induces apoptosis in human hepatoma cells in vitro and inhibits tumor growth in vivo. Pharmacol. Res. 110, 101-110. doi: 10.1016/j.phrs.2016.04.032

Folkman, J. (1971). Tumor angiogenesis: therapeutic implications. N. Engl. J. Med. 285, 1182-1186. doi: 10.1056/NEJM197111182852108 
Folkman, J. (1995). Angiogenesis in cancer, vascular, rheumatoid and other disease. Nat. Med. 1, 27-31. doi: 10.1038/nm0195-27

Gao, X. J., Tong, H. L., Li-Min, L. U., and Qing-Zhang, L. I. (2010). Preparation of dibutyl phthalate isomer from Semen Vaccariae and its influence on milk production and milk quality of dairy cow. China Dairy Indust. 2010, 36-37. doi: 10.3969/j.issn.1001-2230.2010.04.011

Gao, Y. Y., Feng, L., and Qiu, L. Y. (2013). Research on acute toxicology of Vaccaria segetalis extract. Guangzhou Chem. Indust. 41, 17-21. doi: 10.3969/j.issn.1001-9677.2013.19.003

Gao, Y. Y., Qiu, L. Y., Kang, X. X., Wang, H., and Jin, J. (2010). “AntiTumor effect and its mechanism of vaccaria segetalis on mouse inoculated H22 solid carcinoma," in International Conference on Bioinformatics \& Biomedical Engineering WuXi. doi: 10.1109/ICBBE.2010.5517710

Gass, S., Harris, J., Ormandy, C., and Brisken, C. (2003). Using gene expression arrays to elucidate transcriptional profiles underlying prolactin function. J. Mammary Gland Biol. Neoplasia 8, 269-285. doi: 10.1023/B:JOMG.0000010029.85796.63

Guan, F. Q., Liu, M., Yu, S., Chen, Y., Zhao, Y. Y., Wang, M., et al. (2013). The antioxidant activity evaluations of the triterpene saponins from Lonicera macranthoides in vitro. Lishizh. Med. Mater. Med. Res. 24, 1315-1317. doi: $10.3969 /$ j.issn. 1008-0805.2013.06.013

Güçlü-Ustündag, O., and Mazza, G. (2007). Saponins: properties, applications and processing. Crit. Rev. Food Sci. Nutr. 47, 231-258. doi: $10.1080 / 10408390600698197$

Haralampidis, K., Trojanowska, M., and Osbourn, A. E. (2002). Biosynthesis of triterpenoid saponins in plants. Adv. Biochem. Eng. Biotechnol. 75, 31-49. doi: 10.1007/3-540-44604-4_2

Hua'e, J., Caiqin, N., Jianmin, H., and Tuanxiao, Z. (2007). Vasodilatation effects of the water decoction of vaccaria segetalis(neck)garcke on rabbit aorta in vitro. J. Sichu. Tradit. Chin. Med. 25, 13-15.

Hui, Y., Jun-Li, H., and Chuang, W. (2019). Anti-oxidation and anti-aging activity of polysaccharide from Malus micromalus makino fruit wine. Int. J. Biol. Macromol. 121, 1203-1212. doi: 10.1016/j.ijbiomac.2018.10.096

Itokawa, H., Yun, Y., Morita, H., Takeya, K., and Yamada, K. (1995). Estrogenlike activity of cyclic peptides from Vaccaria segetalis extracts. Planta Med. 61, 561-562. doi: 10.1055/s-2006-959373

Jia, Z., Koike, K., Kudo, M., Li, H., and Nikaido, T. (1998). Triterpenoid saponins and sapogenins from Vaccaria segetalis. Phytochemistry 48, 529-536. doi: 10.1016/S0031-9422(97)01128-X

Jing, H., Of, D., Medicine, W., and First, T. (2007). Vasodilatation effects of the water decoction of Vaccaria segetalis(neck) garcke on rabbit aorta in vitro. J. Sichu. Tradit. Chin. Med. 25, 13-15. doi: 10.3969/j.issn.1000-3649.2007. 08.008

Jin-Ling, H. U., Hong, H. U., and Yang, L. (2014). Studies on the chemical constituents from the seeds of Vaccaria segetalis. J. Pharmaceut. Res. 33, 71-72.

Jun-Xian, L. U., Gao, Y. S., Tang, M. J., Jun-Hua, P. U., Zhang, X. Y., and Qing-Lian, G. E. (2013). Effects of free gossypol on immunity of the HISEX young hens. China Anim. Husb. Vet. Med. 40, 118-121. doi: 10.3969/j.issn.1671-7236.2013.04.026

Kabir, E. R., Rahman, M. S., and Rahman, I. (2015). A review on endocrine disruptors and their possible impacts on human health. Environ. Toxicol. Pharmacol. 40, 241-258. doi: 10.1016/j.etap.2015.06.009

Kalu, D. N. (1991). The ovariectomized rat model of postmenopausal bone loss. Bone Miner. 15, 175-191. doi: 10.1016/0169-6009(91)90124-I

Kim, Y., Koh, J. H., Ahn, Y. J., Oh, S., and Kim, S. H. (2015). The Synergic antiinflammatory impact of Gleditsia sinensis Lam. and Lactobacillus brevis KY21 on intestinal epithelial cells in a DSS-induced colitis model. Korean J. Food Sci. Anim. Resourc. 35, 604-610. doi: 10.5851/kosfa.2015.35.5.604

Kleinberg, D. L., and Ruan, W. (2008). IGF-I, GH, and sex steroid effects in normal mammary gland development. J. Mammary Gland Biol. Neoplas. 13, 353-360. doi: $10.1007 /$ s10911-008-9103-7

Koike, K., Jia, Z., and Nikaido, T. (1998). Triterpenoid saponins from Vaccaria segetalis. Phytochemistry 47, 1343-1349. doi: 10.1016/S0031-9422(97)00707-3

Kozlowska, A., and Szostak-Wegierek, D. (2014). Flavonoids-food sources and health benefits. Rocz. Panstw. Zakl. Hig. 65, 79-85.

Leonoudakis, D., Singh, M., Mohajer, R., Mohajer, P., Fata, J. E., Campbell, K. P., et al. (2010). Dystroglycan controls signaling of multiple hormones through modulation of STAT5 activity. J. Cell Sci. 123, 3683-3692. doi: $10.1242 /$ jcs. 070680

Lertkiatmongkol, P., Liao, D., Mei, H., Hu, Y., and Newman, P. J. (2016). Endothelial functions of platelet/endothelial cell adhesion molecule-1 (CD31). Curr. Opin. Hematol. 23, 253-259. doi: 10.1097/MOH.0000000000000239

Li, F., He, T., Xu, Q., Lin, L. T., Li, H., Liu, Y., et al. (2015). What is the acupoint? A preliminary review of acupoints. Pain Med. 16, 1905-1915. doi: $10.1111 /$ pme.12761

Li, K. K., Zhou, X., Wong, H. L., Ng, C. F., Fu, W. M., Leung, P. C., et al. (2016). In vivo and in vitro anti-inflammatory effects of Zao-Jiao-Ci (the spine of Gleditsia sinensis Lam.) aqueous extract and its mechanisms of action. J. Ethnopharmacol. 192, 192-200. doi: 10.1016/j.jep.2016.07.020

Liang, X., and Xiu-jun, J. (2013). Observation on the therapeutic effect of auricular point pressing bean on 30 cases of allergic rhinitis. J. N. Chin. Med. 45, 181-182. doi: CNKI:SUN:REND.0.2013-11-092

Li-Fan, and Liang, J. Y. (2007). Research progress of Vaccaria segetalis. Strait Pharm. J. 19, 1-1.

Liu, J., Limin, L., Xiaofei, L., and Qingzhang, L. (2010). Effects on the proliferation and lactation ability of dairy cow mammary gland epithelial cells by semen vaccariae active isomer. Key Lab. Dairy Sci. Educ. 33, 66-68.

Liu, P. T., Stenger, S., Li, H., Wenzel, L., Tan, B. H., Krutzik, S. R., et al. (2006). Toll-like receptor triggering of a vitamin D-mediated human antimicrobial response. Science 311, 1770-1773. doi: 10.1126/science.1 123933

Liu, Y. (2018). Auricular pressing therapy in the treatment of hypertension for 30 cases. Chin. Med. Mod. Dist. Educ. China. 16:127-128

Liu, Y., Song, F. M., Ma, S. T., Moro, A., and Feng, W. Y. (2019). Vaccarin prevents titanium particle-induced osteolysis and inhibits RANKL-induced osteoclastogenesis by blocking NF-kappaB and MAPK signaling pathways. J. Cell Physiol. 234, 13832-13842. doi: 10.1002/jcp. 28063

Ma, C. H., Fan, M. S., Lin, L. P., Tang, W. D., Lou, L. G., Ding, J., et al. (2008). Cytotoxic triterpenoid saponins from Vaccaria segetalis. J. Asian Nat. Prod. Res. 10, 177-184. doi: 10.1080/10286020701394381

Mao, G. H., Ren, Y., Li, Q., Wu, H. Y., Jin, D., Zhao, T., et al. (2016). Anti-tumor and immunomodulatory activity of selenium (Se)-polysaccharide from Se-enriched Grifola frondosa. Int. J. Biol. Macromol. 82, 607-613. doi: 10.1016/j.ijbiomac.2015.10.083

Mao, X., Guo, H., Yao, R., Bao, L., Sun, J., Bao, Y., et al. (2020). Crude polysaccharides from the seeds of Vaccaria segetalis prevent the urinary tract infection through the stimulation of kidney innate immunity. $J$. Ethnopharmacol. 260:112578. doi: 10.1016/j.jep.2020.112578

Mao, X., Yao, R., Guo, H., Bao, L., Bao, Y., Xu, Y., et al. (2021). Polysaccharides extract from Vaccaria segetalis seeds inhibits kidney infection by regulating cathelicidin expression. J. Ethnopharmacol. 267:113505. doi: $10.1016 /$ j.jep.2020.113505

Mark, Shoemaker, M., Hamilton, B., Dairkee, S. H., Cohen, I., and Campbell, M. J. (2005). In vitro anticancer activity of twelve Chinese medicinal herbs. Phytother. Res. 19:649-51. doi: 10.1002/ptr.1702

Minliangzou, Z., and Ainalao, S. (1999). Segetoside L, a new triterpenoid saponin from Vaccaria segetalis. ??????(???)15, 55-57.

Min-ying, T. (2005). 59 cases of herpes zoster treated with Vaccaria segetalis. Chin. J. Rural Med. Pharm. 13, 51-51. doi: CNKI:SUN:XCYY.0.2006-06-053

Morita, H., Eda, M., Iizuka, T., Hirasawa, Y., Sekiguchi, M., Yun, Y. S., et al. (2006). Structure of a new cyclic nonapeptide, segetalin F, and vasorelaxant activity of segetalins from Vaccaria segetalis. Bioorgan. Med. Chem. Lett. 16, 4458-4461. doi: 10.1016/j.bmcl.2006.06.083

Morita, H., Nagashima, S., Takeya, K., and Itokawa, H. (1993). Astins A and B, antitumor cyclic pentapeptides from Aster tataricus. Chem. Pharm. Bull. 41, 992-993. doi: $10.1248 / \mathrm{cpb} .41 .992$

Morita, H., Yun, Y. S., Takeya, K., and Itokawa, H. (1997a). Conformational preference for segetalins $\mathrm{G}$ and $\mathrm{H}$, cyclic peptides with estrogen-like activity from seeds of Vaccaria segetalis. Bioorgan. Med. Chem. 5, 2063-2067. doi: 10.1016/S0968-0896(97)00135-1

Morita, H., Yun, Y. S., Takeya, K., Itokawa, H., and Shiro, M. (1995). Conformational analysis of a cyclic hexapeptide, segetalin A from Vaccaria segetalis.? Tetrahedron 51, 5987-6002. doi: 10.1016/0040-4020(95)00277-F 
Morita, H., Yun, Y. S., Takeya, K., Itokawa, H., and Shirota, O. (1997b). Thionation of segetalins A and B, cyclic peptides with estrogen-like activity from seeds of Vaccaria segetalis. Bioorgan. Med. Chem. 5, 631-636. doi: 10.1016/S0968-0896(97)00001-1

Morita, H., Yun, Y. S., Takeya, K., Itokawa, H., Yamada, K., Shirota, O., et al. (1997c). A new triterpenoid saponin with contractility of rat uterine from Vaccaria segetalis. Bioorg. Med. Chem. Lett. 7, 1095-1096. doi: 10.1016/S0960-894X(97)00168-6

Othman, A. A., Abou Rayia, D. M., Ashour, D. S., Saied, E. M., Zineldeen, D. H., and El-Ebiary, A. A. (2016). Atorvastatin and metformin administration modulates experimental Trichinella spiralis infection. Parasitol. Int. 65, 105-112. doi: 10.1016/j.parint.2015.11.001

Pakoussi, T., Mouzou, A. P., Metowogo, K., Aklikokou, K. A., and Gbeassor, M. (2018). How do Spondias mombin L (Anacardiaceae) leaves extract increase uterine smooth muscle contractions to facilitate child birth in parturient women? Afr. Health Sci. 18, 235-243. doi: 10.4314/ahs.v18i2.6

Passaniti, A., Taylor, R. M., Pili, R., Guo, Y., Long, P. V., Haney, J. A., et al. (1992). A simple, quantitative method for assessing angiogenesis and antiangiogenic agents using reconstituted basement membrane, heparin, and fibroblast growth factor. Lab Invest. 67, 519-528.

Peng, Q., Feng, Z., Rui, X., Zhixiong, L., Mingcang, C., Zhaolin, S., et al. (2014). Identification of multiple constituents from seed of Vaccaria segetalis with an adsorbent-separation strategy based on liquid chromatography coupled to quadrupole time-of-flight mass spectrometry. Rapid Commun. Mass Spectrom. 28, 1243-1257. doi: 10.1002/rcm.6893

Planas-Silva, M. D., Waltz, P. K., and Kilker, R. L. (2006). Estrogen induces death of tamoxifen-resistant MCF-7 cells: contrasting effect of the estrogen receptor downregulator fulvestrant. J. Steroid Biochem. Mol. Biol. 98, 193-198. doi: 10.1016/j.jsbmb.2005.10.003

Qing, L. I., Pan, Z. L., Jie, W. U., and Zhang, H. J. (2014). Study on extraction process and content determination of polysaccharides from Semen vaccaria. Sci. Technol. Food Indust. 35:299-299.

Qiu, Y., Du, B., Xie, F., Cai, W., Liu, Y., Li, Y., et al. (2016). Vaccarin attenuates high glucose-induced human EAâ? chy926 endothelial cell injury through inhibition of notch signaling. Mol. Med. Rep. 13, 2143-2150. doi: 10.3892/mmr.2016.4801

Rong, P., Zhu, B., Li, Y., Gao, X., Ben, H., Li, Y., et al. (2011). Mechanism of acupuncture regulating visceral sensation and mobility. Front. Med. 5, 151-156. doi: 10.1007/s11684-011-0129-7

Rosalía, R. R., María Dolores, H., Perona, J. S., and Valentina, R. G. (2004). Potential vasorelaxant effects of oleanolic acid and erythrodiol, two triterpenoids contained in 'orujo' olive oil, on rat aorta. Br. J. Nutr. 92, 635-642. doi: 10.1079/BJN20041231

Rostami, A., Gamble, H. R., Dupouy-Camet, J., Khazan, H., and Bruschi, F. (2017). Meat sources of infection for outbreaks of human trichinellosis. Food Microbiol. 64, 65-71. doi: 10.1016/j.fm.2016.12.012

Sang, S., Lao, A., Chen, Z., Uzawa, J., and And, Y. F. (2003). "Chemistry and bioactivity of the seeds of Vaccaria segetalis," in ACS Symposium Series Shanghai. doi: 10.1021/bk-2003-0859.ch021

Sang, S., Lao, A., Wang, H., Chen, Z., Uzawa, J., and Fujimoto, Y. (1999). Triterpenoid saponins from Vaccaria segetalis. J. Asian Nat. Prod. Res. 1, 199-205. doi: 10.1080/10286029908039865

Sang, S. M., Lao, A., Leng, Y., Gu, Z., Chen, Z., Uzawa, J., et al. (2000d). Segetoside F a new triterpenoid saponin with inhibition of luteal cell from the seeds of Vaccaria segetalis. Tetrahed. Lett. 41, 9205-9207. doi: 10.1016/S0040-4039(00)01710-X

Sang, S. M., Lao, A. N., Chen, Z. L., Uzawa, J., and Fujimoto, Y. (2000b). Three new triterpenoid saponins from the seeds of Vaccaria segetalis. J. Asian Nat. Prod. Res. 2, 187-193. doi: 10.1080/10286020008039910

Sang, S. M., Lao, A. N., Leng, Y., Cao, L., Chen, Z. L., Uzawa, J., et al. (2002). A new triterpenoid saponin with inhibition of luteal cell from the seeds of Vaccaria segetalis. J. Asian Nat. Prod. Res. 4, 297-301. doi: 10.1080/1028602021000049096

Sang, S. M., Xia, Z. H., Mao, S. L., Lao, A., and Chen, Z. L. (2000c). [Studies on the flavonol glycosides from the seeds of Vaccaria segetalis]. Zhongguo Zhong Yao Za Zhi 25, 221-222.

Sang, S. M., Zou, M. L., Lao, A. N., Liang, Z., and Fujimoto, Y. (2000a). A new triterpenoid saponin from the seeds of Vaccaria segetalis. ??????(???)11, 49-52. doi: $10.1021 / \mathrm{cm} 990982 \mathrm{a}$
Schieber, M., and Chandel, N. S. (2014). ROS function in redox signaling and oxidative stress. Curr. Biol. 24, R453-462. doi: 10.1016/j.cub.2014.03.034

Shih, C. C., Lin, C. H., and Lin, W. L. (2009). Ameliorative effects of Vaccaria segetalis extract on osteopenia in ovariectomized rats. J. Nat. Med. 63, 386-392. doi: $10.1007 /$ s1 1418-009-0341-9

Shiva Kumar, A., Jeyaprakash, K., Chellappan, D. R., and Murugan, R. (2017). Vasorelaxant and cardiovascular properties of the essential oil of Pogostemon elsholtzioides. J. Ethnopharmacol. 199, 86-90. doi: 10.1016/j.jep.2017.01.036

Silva, B., Guedes, J. M., Arêde, A., and Costa, A. (2012). Synthesis and bioactivity of secondary metabolites from marine sponges containing dibrominated indolic systems. Cheminform 17:6083. doi: 10.3390/molecules17056083

Sun, H., Cai, W., Wang, X., Liu, Y., Hou, B., Zhu, X., et al. (2017). Vaccaria hypaphorine alleviates lipopolysaccharide-induced inflammation via inactivation of NFkappaB and ERK pathways in Raw 264.7 cells. BMC Complement. Alternat. Med. 17:120. doi: 10.1186/s12906-017-1635-1

Sun, J., Paddock, C., Shubert, J., Zhang, H. B., Amin, K., Newman, P. J., et al. (2000). Contributions of the extracellular and cytoplasmic domains of plateletendothelial cell adhesion molecule-1 (PECAM-1/CD31) in regulating cell-cell localization. J. Cell Sci. 113 (Pt. 8), 1459-1469. doi: 10.1023/A:1005568132027

Tan, N. H., and Zhou, J. (2006). Plant cyclopeptides. Chem. Rev. 106, 840-895. doi: $10.1021 / \mathrm{cr} 040699 \mathrm{~h}$

Tang, X., Huang, J., Xiong, H., Zhang, K., Chen, C., Wei, X., et al. (2016). Anti-Tumor Effects of the polysaccharide isolated from tarphochlamys affinis in H22 tumor-bearing mice. Cell. Physiol. Biochem. 39, 1040-1050. doi: 10.1159/000447811

Tian-Yi, L. (2011). Precious Mirror of Health. Shijiazhuang: China Medical Science Technology Press.

Tímár, J., Döme, B., Fazekas, K., Janovics, A., and Paku, S. (2001). Angiogenesisdependent diseases and angiogenesis therapy. Pathol. Oncol. Res. 7, 85-94. doi: 10.1007/BF03032573

Tong, H., Gao, X., Li, Q., Liu, J., Li, N., and Wan, Z. (2011). Metabolic regulation of mammary gland epithelial cells of dairy cow by galactopoietic compound isolated from Vaccariae segetalis. Agric. Sci. China 10, 1106-1116. doi: 10.1016/S1671-2927(11)60100-4

Tong, H., Gao, X., Sheng, Z., Li, Q., Li, S., Li, N., et al. (2013). Galactopoietic activity of dibutyl phthalate isolated from Vaccaria segetalis. J. Northeast Agric. Univ., 20, 28-33. doi: 10.1016/S1006-8104(14)6 0043-X

Tuffrey, M., Alexander, F., Woods, C., and Taylor-Robinson, D. (1992). Genetic susceptibility to chlamydial salpingitis and subsequent infertility in mice. $J$. Reprod. Fertil. 95, 31-38. doi: 10.1530/jrf.0.0950031

Vandamme, D., Landuyt, B., Luyten, W., and Schoofs, L. (2012). A comprehensive summary of LL-37, the factotum human cathelicidin peptide. Cell. Immunol. 280, 22-35. doi: 10.1016/j.cellimm.2012. 11.009

Viallard, C., and Larrivee, B. (2017). Tumor angiogenesis and vascular normalization: alternative therapeutic targets. Angiogenesis 20, 409-426. doi: 10.1007/s10456-017-9562-9

Vitagliano, D., De Falco, V., Tamburrino, A., Coluzzi, S., Troncone, G., Chiappetta, G., et al. (2010). The tyrosine kinase inhibitor ZD6474 blocks proliferation of RET mutant medullary thyroid carcinoma cells. Endocr. Relat. Cancer 18, 1-11. doi: 10.1677/ERC-09-0292

Wang, F., Chen, S., Deng, L., Chen, L., Huang, Y., Tian, M., et al. (2019). Protective effects of astragaloside IV against LPS-induced endometritis in mice through inhibiting activation of the NF-kappaB, p38 and JNK signaling pathways. Molecules 24:373. doi: 10.3390/molecules24 020373

Wang, L., Cui, D., Wang, X., Zhang, J., Yang, Z., Qin, Z., et al. (2015). Analgesic and anti-inflammatory effects of hydroalcoholic extract isolated from Semen vaccariae. Pak. J. Pharm. Sci. 28(3 Suppl), 1043-1048

Wang, X., Dong, H., Liu, Y., Yang, B., Wang, X., and Huang, L. (2011). Application of high-speed counter-current chromatography for preparative separation of cyclic peptides from Vaccaria segetalis. J. Chromatogr. B 879, 811-814. doi: 10.1016/j.jchromb.2011.02.001

Wei, C. M., Su, Y. J., Qin, X., Ding, J. X., Liu, Q., Song, F. M., et al. (2018). Monocrotaline suppresses RANKL-induced osteoclastogenesis in vitro and prevents LPS-induced bone loss in vivo. Cell. Physiol. Biochem. 48, 644-656. doi: $10.1159 / 000491892$ 
Xie, F., Cai, W., Liu, Y., Li, Y., Du, B., Feng, L., et al. (2015). Vaccarin attenuates the human EA.hy926 endothelial cell oxidative stress injury through inhibition of notch signaling. Int. J. Mol. Med. 35, 135-142. doi: 10.3892/ijmm.2014. 1977

Xu, F., Hou, B., Zhu, X., Liu, Y., Shi, X., Li, S., et al. (2019). Vaccaria nbutanol extract lower the production of proinflammatory cytokines and the infection risk of $T$. spiralis in vivo. Acta Parasitol. 64, 520-527. doi: 10.2478/s11686-019-00064-6

Yu, Y., Yuan, X., Li, P., Wang, Y., Yu, M., and Gao, X. (2020). Vaccarin promotes proliferation of and milk synthesis in bovine mammary epithelial cells through the Prl receptor-PI3K signaling pathway. Eur. J. Pharmacol. 880:173190. doi: 10.1016/j.ejphar.2020.173190

Yun, Y. S., Morita, H., Takeya, K., and Itokawa, H. (1997). Cyclic peptides from higher plants. 34. Segetalins $\mathrm{G}$ and $\mathrm{H}$, structures and estrogen-like activity of cyclic pentapeptides from Vaccaria segetalis. J. Nat. Prod. 60, 216-218. doi: $10.1021 / \mathrm{np} 960617 \mathrm{n}$

Yun, Y. S., Shimizu, K., Morita, H., Takeya, K., Itokawa, H., and Shirota, O. (1998). Triterpenoid saponin from Vaccaria segetalis. Phytochemistry 47, 143-144. doi: 10.1016/S0031-9422(97)00496-2

Zakaryan, H., Arabyan, E., Oo, A., and Zandi, K. (2017). Flavonoids: promising natural compounds against viral infections. Arch. Virol. 162, 2539-2551. doi: 10.1007/s00705-017-3417-y

Zhang, L. J., Zhu, J. Y., Sun, M. Y., Song, Y. N., Rahman, K., Peng, C., et al. (2017). Anti-inflammatory effect of Man-Pen-Fang, a Chinese herbal compound, on chronic pelvic inflammation in rats. J. Ethnopharmacol. 208, 57-65. doi: 10.1016/j.jep.2017.06.034

Zheng, J., Ma, L. T., Ren, Q. Y., Li, L., Zhang, Y., Shi, H. J., et al. (2014). The influence of astragalus polysaccharide and beta-elemene on
LX-2 cell growth, apoptosis and activation. BMC Gastroenterol. 14:224. doi: 10.1186/s12876-014-0224-8

Zheng, T., Chen, W., Hu, H., Wang, Y., Harnett, J. E., and Ung, C. O. L. (2020). The prevalence, perceptions and behaviors associated with traditional/complementary medicine use by breastfeeding women living in Macau: a cross-sectional survey study. BMC Complement. Med. Ther. 20:122. doi: 10.1186/s12906-020-02921-8

Zhi-hong, Y., and Cai-ying, S. (1989). The effect of auricular plaster on gallbladder contraction. J. Gansu Coll. Trad. Chin. Med. $1,31-32$.

Zhou, G., Tang, L., Wang, T., Zhou, X., and Wang, Z. (2015). Phytochemistry and pharmacological activities of Vaccaria hispanica (miller) rauschert: a review. Phytochem. Rev. 15, 813-827. doi: 10.1007/s11101-0159425-1

Zhu-mo, N. (2005). Materia Medica (Selected Chinese Ancient Books). Shanghai: Shanghai Science and Technology Press.

Conflict of Interest: The authors declare that the research was conducted in the absence of any commercial or financial relationships that could be construed as a potential conflict of interest.

Copyright (c) 2021 Tian, Huang, Wang, Cao, Zhao, Chen, Yuan, Wang, Zhang, Li and Zhou. This is an open-access article distributed under the terms of the Creative Commons Attribution License (CC BY). The use, distribution or reproduction in other forums is permitted, provided the original author(s) and the copyright owner $(s)$ are credited and that the original publication in this journal is cited, in accordance with accepted academic practice. No use, distribution or reproduction is permitted which does not comply with these terms. 